\title{
Müzik Öğretmenlerinin Kaynaştırma Öğrencilerinin Şarkı ve Çalgı Eğitimlerine İliş̧kin Görüşleri
}

\section{Music Teachers' Opinions on Teaching Song And Instrument to Inclusive Students}

\author{
Mehmet Şahin AKINCI*, Uğur ALPAGUT**
}

Öz: Zihinsel, fiziksel ve duygusal açılardan yaşıtlarından farklı gelişim gösteren öğrenciler özel gereksinimli öğrenci (ÖGÖ) olarak adlandırılmaktadır. ÖGÖ’ler normal gelişim gösteren arkadaşları ile ve/veya gereksinim durumlarına göre farklı okullarda eğitimlerini sürdürmektedirler. ÖGÖ’ler kendileri için hazırlanmış eğitim/öğretim planları ve öğretmenler ile gelişimlerini sürdürmektedirler. Müzik öğretmenlerinin ÖGÖ’lerin şarkı eğitimi ve çalgı eğitimi üzerine görüşlerini tespit etmek amacıyla Bolu ili merkez ilçesinde çalışmakta olan on müzik öğretmenine araştırmacılar tarafından oluşturulmuş olan yarı yapılandırılmış görüşme formu uygulanmıştır. Alınan cevaplar içerik analizi yöntemi ile incelenmiş konuya ilişskin durum tespiti yapılmış, tespitler alan uzmanlarına sunulmuş ve onayları alınmıştır. Şarkı eğitimi aşamasında öğrencilerin dramalaştırma, çeşitli beden hareketleri ve uygun ritim çalgıları kullanmaları sayesinde ilgi ve başarının artırılabildiği; çalgı eğitimi aşamasında ise öğrencilerin şarkı eğitimine göre daha az katılım sağladıkları ve tekniğe uygun performans göstermede yetersiz olduklarına ulaşılmıştır. ÖGÖ'lerin genel müzik derslerinden başka sınıf ve zamanlarda ek müzik çalışmaları yapılmasının daha fazla katkı sağlayabileceği düşünülmektedir.

Anahtar Kelimeler: Kaynaştırma öğrencileri, kaynaştırma yoluyla eğitim, müzik öğretmenliği, şarkı ve çalg1 eğitimi

\begin{abstract}
Students who demonstrate different mental, physical and emotional developments compared to their peers are defined as students with special needs (SWSN). SWSNs pursue their education at general educational environments with their friends who reveal normal developmental features, and/or at schools offering special education, depending on the type of their needs. SWSNs proceed their education with the help of teachers and curriculums designed for them. Aim of this study is to identify the opinions of music teachers on teaching songs and instruments to SWSNs. With this object in mind, a semi-structured interview form developed by the researchers have been applied to a total of ten music teachers working at the central district of Bolu province. The answers have been analyzed through content analysis method; state assessment has been conducted, and the assessments have been submitted for the approval of field specialists. The study concluded that the attention and achievements of students can be increased with the help of dramatization, various body movements and suitable rhythm instruments at the stage of song teaching; while in instrument teaching the students are found to show less attendance when compared to singing and that they have inadequacies while performing in accordance with the technique. It is also believed that additional musical activities besides the general music lesson may contribute to the development of SWSNs.
\end{abstract}

Keywords: Inclusive students, inclusive education, music teaching, song and instrument teaching

\section{Giriş}

Fiziksel, duygusal, sosyal ve zihinsel özellikleri bütünüyle kapsayan gelişim ve gelişim evreleri, araştırmalar ve bilimsel kanıtlar yardımıyla insanların doğumundan itibaren başlayacak şekilde aşamalandırılmış ve değişimler tespit edilmiştir. Bu tespitler sonunda genel/beklenen gelişim özelliklerinden başka her bireyin diğer bireylerden farklı düşünsel, duygusal, zihinsel ve fiziksel özelliklerde olabileceği görülmüştür. Bazı bireyler diğer bireylere göre daha yavaş veya daha

\footnotetext{
* Dr. Öğr. Üyesi, Zonguldak Bülent Ecevit Üniversitesi, Devlet Konservatuvarı, Zonguldak-Türkiye, ORCİD: 00000002-2404-330X, e posta: mehmetsahinakinci@hotmail.com

** Prof. Dr., Bolu Abant İzzet Baysal Üniversitesi, Eğitim Fakültesi, Bolu-Türkiye, ORCID: 0000-0001-6503-0022, e-posta: alpagutugur@yahoo.com
} 
hızlı gelişim özellikleri gösterebilmektedir. Bu özellikleri itibariyle bu bireyler özel gereksinimli bireyler ve bu doğrultuda özel eğitime ihtiyacı olan bireyler olarak nitelendirilebilmektedir. Kişisel özellikleri doğrultusunda gelişime ve öğrenmeye ihtiyacı olan bu bireyler de bilgiyi ve deneyimi farklı yollar ve gereksinimlerle kazanabilme kapasitelerinden dolayı eğitim faaliyetlerini farklı ortam ve amaçlarla özel eğitim faaliyetleri kapsamında sürdürmektedirler.

Yeteneklerinin desteklenmesinde ve biçimlendirmesinde yoğunlukla desteğe ihtiyaç duyan grup, özel gereksinimli bireylerdir. Bu bireyler "farklı", "özel”, "sıra dışı" vb. şekilde nitelendirilebilmektedir (Varış ve Hekim, 2017, 30). Özel eğitime ihtiyacı olan birey çeşitli nedenlerle, bireysel özellikleri ve eğitim yeterlilikleri açısından yaşıtlarından beklenilen düzeyden anlamlı farklılık gösteren bireylerdir (MEB, 2000, Özel Eğitim Hizmetleri Tanıtım El Kitabı; MEB, Özel Eğitim ve Rehabilitasyon Merkezi Zihinsel Engelli Bireyler Destek Eğitim Programı, 2008). Belirtilen bireysel farklılıkların yanı sıra, bireyler arasında günlük ve toplumsal yaşamın bir parçası olan temel becerilerin ve kişisel sorumlulukların yerine getirilmesine engel olan bireysel farklılıklar da bulunabilmektedir (Özkan Yaşaran, 2009). Fiziksel, duygusal, sosyal yetersizlik ve zihin yetersizliği olmak üzere gelişimsel yetersizliği olan çocuklar dört bölüme ayrilır (Carey, 1960). Kalıtımsal miras, sonradan edinilmiş engeller, yanlış öğrenmeler ve eksiklikler sonucunda bedende sosyal, duygusal ve zihinsel farklılıklar ortaya çıkar. Bu farklılıklar bireye bazen olumlu bazen de olumsuz kazançlar sağlayabilir. Fakat özel gereksinimli olarak nitelendirilebilmekte olan bireyler ortalamanın üstünde zorluklarla karşılaşabilmektedirler (Kulaksızoğlu, 2015).

Yetersizlikler bireyin sosyal, duygusal, zihin, akademik, kültürel ve daha sayılabilecek birçok alanda gelişimine olumsuz etkiler sağlayabilir. Belirli derecede fiziksel yetersizlik dışında kalan yetersizliklerin eğitim açısından bakıldığında eğitim faaliyetlerini doğrudanolumsuz etkileyebilecek ve güçleştirebilecek önem ve güçte olduğu söylenebilir. ÖGÖ’ler eğitimlerini yetersizliklerine uygun olarak açılmış olan (görme engelliler, zihin engelliler vb) okullarda ve genel eğitim okullarında normal gelişim gösteren arkadaşları ile sürdürmektedirler. $\mathrm{Bu}$ uygulamalar özel eğitim hizmetleri kanunları ile sürdürülmekte ve takip edilmektedir (Akınc1 ve Alpagut, 2017).

Günümüzde çağdaş eğitim, bireylerin gereksinimleri doğrultusunda hizmet sunmak üzere bireysel farklılıklar dikkate alınarak planlanmaya başlamıştır. Dolayısıyla ÖGÖ’leri topluma kazandırmak amacıyla onların mevcut bedensel, zihinsel ve sosyal becerilerini geliştirecek şekilde eğitim gereksinimlerinin karşılanması önem kazanmıştır (Diken ve Sucuoğlu, 1999). ÖGÖ’lerin eğitimi onlara sağlanan eğitim faaliyetlerinden en iyi şekilde yararlanmaları için önceden hazırlanmış olan ortamlarda yürütülmektedir (Çakıroğlu, 2016). Özel eğitim hizmetleri, ülkemizde özel gereksinimli bireylerin yaşıtlarından ayrı olarak eğitim aldıkları özel eğitim kurumlarında ya da kaynaştırma yoluyla eğitim uygulaması adı altında normal ve özel gereksinimli bireylerin birlikte eğitim alması yoluyla gerçekleştirilmektedir (Güven, 2011). Kaynaştırma, Özel Eğitim Hizmetleri Yönetmeliğine bağlı olarak her tür ve kademede, özel eğitime ihtiyacı olan bireyler ve yetersizliği olmayan bireylerin (MEB, 2015, Kaynaştırma Yoluyla Eğitim Uygulamaları Kitapçığı), örgün ve yaygın eğitim ortamlarında (MEB, 2016, Milli Eğitim İstatistikleri), özel eğitim desteğinde eğitimlerini sürdürmesidir (Kargın, 2004). "Kaynaştırma: Özel eğitim gerektiren bireylerin, yetersizliği olmayan akranları ile birlikte eğitim ve öğretimlerini resmî ve özel okul öncesi, ilköğretim, orta öğretim ve yaygın eğitim kurumlarında sürdürmeleri esasına dayanan destek eğitim hizmetlerinin sağlandığı özel eğitim uygulamalarıdır" (MEB, 2000:4/d). Genel eğitim sınıfında bulunan ÖGÖ'lerin eğitimlerinin özel eğitim desteği ile sürdürmesidir (Sucuoğlu ve Kargın, 2010, 25). Belirli durumlarda ÖGÖ'ler için özel sınıflar açılmaktadır (MEB, 2015, Kaynaştırma Yoluyla Eğitim Uygulamaları Kitapçı̆̆ı).

Normal gelişim gösteren arkadaşları ile aynı eğitim ortamlarında eğitim alan kaynaştırma öğrencileri birbirlerinden farklı sayı ve niteliklerde dersler almaktadırlar. Müzik dersi de teorik ve uygulamalı olarak aldıkları derslerden bir tanesidir. Müzik dersi, öğrencilerin birbirleriyle etkileşiminin yoğun olarak yaşandığı, öğrencilerin kendilerini hem bireysel, hem de gruplar halinde ifade edebilmelerine olanak sağlayan bir derstir. Müzik dersinin bu özellikleri 
ÖGÖ'lerin sosyal becerilerinin gelişmesinde ve sosyal yönden kabul edilmeleri üzerinde etkili olabilmektedir (Akıncı ve Alpagut, 2017). Kaynaştırma öğrencilerinin müzik derslerindeki önemli amaç tüm öğrenciler için uygun müzikal öğrenme ortamı yaratmaktır. Bunun için fiziksel çevrede, öğretim materyallerinde ve öğretim yöntemlerinde belirli uyarlamalar yapmak gerekmektedir (Güven ve Tufan, 2010). Müzik eğitiminde program ile ilişkili olarak belirlenmiş çeşitli ders materyalleri, araç-gereçler kullanılmaktadır. Çalgılar ve şarkılar müzik dersinin iki önemli materyali-aracıdır (Akıncı, 2017). Şarkı ve çalg1 eğitimi bireylerin tüm gelişim alanlarını olumlu etkilemekle birlikte grup çalışmaları, yaratıcılığı geliştirme faaliyetleri, sosyal ortamlarda girişimcilik ve kendini ifade edebilme gibi alanlarda olumlu katkılar sağlamaktadır. Özellikle özel eğitim alanında birçok öğretim yönteminde müzik (şarkılar, çalgılar vb.) ağırlıklı olarak tercih edilmekte ve araştırmaların önemli yardımcısı olmaktadır.

Kaynaştırma yoluyla eğitimin başarıya ulaşmasında sınıftaki diğer öğrencilerin tutumları, öğretmenin yaklaşımı ve öğretimsel uyarlamaların da büyük önemi olduğu bilinmektedir (Güven, 2011). Bu eğitim, hazırlanan bireysel eğitim planları doğrultusunda, uygun yöntem ve teknikler kullanılarak sürdürülmektedir (Palancı, 2013). Ancak kaynaştırma yoluyla eğitim ortamlarında ÖGÖ'lerin çeşitli nedenlerle hem diğer ders alanları hem de konumuz açısından müzik dersinin olumlu etkilerinden yeterince faydalanamadıkları düşünülmektedir. Bu konuya öğretmen yetiştirme görevi verilmiş yükseköğretim kurumu olan eğitim fakültelerinin uygulamış olduğu eğitim programı üzerinden değinilebilir.

2006-2007 akademik yılından itibaren uygulamaya konan öğretmen yetiştirme programlarında tüm bölümlere özel eğitim dersi konulmuştur. Ancak daha önceki yıllarda mezun olan öğretmenlerin büyük bölümü bu dersten yararlanamamışlardır. 2006-2007 eğitim öğretim y1lından önce mezun olanlar da özel eğitim dersinin gerekliliği ve önemi üzerinde durulmadan başka bir ek özel eğitim kurs, seminer veya eğitim faaliyetine alınmamışlardır. Bu bakımdan belirli bir çoğunluktaki müzik öğretmeninin farklı ihtiyaçları ve gereksinimleri olan ÖGÖ’ler konusunda ve onların müzik eğitimleri konusunda yeterince bilgilendirilmemiş olmaları fark edilebilecek kadar açık olmaktadır.

Eğitim fakültelerinde özel eğitim dersi çoğunlukla bu alanın uzmanları (özel eğitim bölümü öğretim elemanları) tarafından yürütülmektedir. $\mathrm{Bu}$ açıdan bakıldığında müzik öğretmeni adaylarının özel eğitim dersinde öğrendikleri özel eğitim alanına ilişkin bilgileri kendi mesleki çalışmalarıyla nasıl birleştirecekleri ile ilgili bilgi ve çalışmalar eksik kalmaktadır. $\mathrm{Bu}$ durumda, müzik öğretmeni adayları bu derste, kaynaştırma uygulaması kapsamında sınıflarında bulunacak olan özel gereksinimli bireylere karşı nasıl bir tutum içinde olacaklarına, "onlar ile" ve "onlar için" yapılabilecek düzenlemelere, programlamalara, uygulamalara ve mevcut uygulamalarda yapacakları uyarlamalara ilişkin yeterli bilgi ve donanım kazanma şansı bulamamaktadırlar. Üniversitelerimizde ise bu eksikleri işlevsel açıdan giderecek nitelikte kuramsal ve/veya uygulamalı çalışmalar yürütülmediği düşünülmektedir. Yürütüldüğü varsayılan eğitimler ve uygulamalar ise tamamen o dersi veren öğretim görevlisinin bu alandaki eğitim ve yeterliliğiyle sınırlı kalmaktadır (Eren, 2012).

Özel eğitim alanında yeterli bilgi ve donanıma sahip olamayan müzik öğretmenlerinin yanlışsız ve doğal öğretim yöntemleri gibi özel eğitimde kullanılan yöntem ve yaklaşımlar hakkında bilgi sahibi olmaları ve bu yöntemlerle işbirliği içinde bir müzik eğitimi anlayışını benimsemeleri kolaylaştırıcı unsur olarak görülebilir. Ancak yine de bir müzik öğretmeninin bilgi ve donanım açısından güçlü olduğu alan müzik eğitimi alanıdır (Eren, 2012). Öğretmenler genellikle ÖGÖ sınıfta yokmuş gibi davranmakta, öğrencinin gereksinimlerine cevap verememektedir. Öğretmenin olumsuz tutumu sınıf ortamını etkilemekte ve sınıftaki diğer öğrencilerin, farklılıkları olan öğrencileri sosyal olarak kabul etme düzeyleri düşmektedir (Batu, 1998; Diken ve Sucuoğlu, 1999; Güven, 2011).

İşitsel yeteneği olan bir kaynaştırma öğrencisi okulundaki koro faaliyetlerine katılarak toplu söyleme alışkanlığ kazanabilir. Hiperaktif öğrenciler müzik derslerinde dans ve çeşitli hareketli etkinliklere katılabilir ve kendi istekleri ile ders içinde aktif olabilirler. Kimi öğrenciler kendi içlerinde yaşadıkları güçlük ve yetersizliklerden dolayı çekingen olabilirler. $\mathrm{Bu}$ gibi durumlarda öğretmene dikkatli olma görevi düşmekte ve öğretmenler cesaretlendirici olmalıdır 
(Güven, 2011). Bu bağlamda eğitim ve öğretimin temel dayanak noktası olan öğretmenlerden eğitimin başından sonuna kadar kontrollü olması, dikkatli hazırlanmış planlarla eğitim faaliyetlerini sürdürmesi ve kendini geliştirebilecek girişimci ruha sahip olmaları beklenmektedir.

Araştırmalar, öğretmenlerin ÖGÖ’lere ve kaynaştırma öğrencilerine yönelik tutumlarının öğretmenlerin bu öğrencilere verdikleri eğitimi becerebilmeleri açısından yeterli hissedip hissedememeleri durumları ile ilişkili olduğunu belirtmektedir. Yetersiz hisseden öğretmenlerin kaynaştırma konusunda isteksiz olduğu da bilinmektedir (Kırcaali İftar, 1992; Uysal 2004). Öğretmenler kaynaştırmanın tanımı da dahil olmak üzere bu eğitim çeşidinin içeriğini bilmediklerini, hazırlık evresinden destek eğitimi evresine kadar edinmiş olmaları gereken deneyime sahip olmadıklarını belirtmişlerdir (Batu, 1998; Baykoç Dönmez, Avc1, Aslan, 1997; Güven ve Tufan, 2010; Uysal, 1995; 2004). Araştırmanın genel çerçevesi olan özel gereksinimli öğrencilerin müzik eğitimi konusuna yakın başlıklarda araştırmalar mevcuttur. Bunlardan birisi Aktaş ve Çifci Tekinarslan (2016) tarafindan yapılmış olan "Müzik Öğretmenlerinin Kaynaştırma Öğrencilerine Yönelik Yaptıkları Öğretim Uyarlamalarının Belirlenmesi" başlıklı çalışmadır. $\mathrm{Bu}$ çalışmada müzik öğretmenlerinin kaynaştırma öğrencilerinin müzik derslerine olan ilgilerine dikkat ederek planlama, ders süresi ve fiziki ortam saptama, materyal belirleme ve başarı değerlendirme yaptıkları sonuçlarına ulaşılmıştır.

Araştırmanın, alanda çalışmakta olan müzik öğretmenlerinin konuya ilişkili olarak sundukları görüşler yardımıyla durumun incelenmesi ve tespit edilen sorunlara dikkat çekip çözüm önerileri sunabilmesi; ÖGÖ'lerin sanat ve müzik alanında sınırlı sayıda yapılmış ve bu açıdan eksik kalmış çalışmalara örnek olarak literatüre kazandırılmış bir çalışma olması ve bu bakımdan diğer araştırmacıları da teşvik edebilme gücünün olması; müzik öğretmenlerinin bu alanda kendilerini geliştirebilmesi ve bilgilendirmesi açısından dikkat çekici noktalara değinmiş olması bakımından önem taşıdığı düşünülmektedir.

"Kaynaştırma öğrencilerinin şark1 ve çalg1 eğitimlerine ilişkin müzik öğretmenlerinin görüşleri nelerdir" araştırma probleminden yola çıkarak çalışılmış olan bu araştırmanın amacı müzik öğretmenlerinin kaynaştırma eğitimi öğrencilerine verdikleri şarkı ve çalgı eğitiminde karşılaştıkları sorunları yine alanda çalışmakta olan müzik öğretmelerinin görüşleri ile ortaya çıkarmak ve tespit edilen problemlere ilişkin görüş ve öneriler sunmaktır.

\section{Yöntem}

Araştırma için öncelikle özel eğitim, kaynaştırma yoluyla eğitim, ÖGÖ’ler ve eğitimleri başlıklarından yola çıkılarak 2005-2014 yılları arasında yapılmış müzik öğretmenlerinin ve müzik dersine giren öğretmenlerin görüşlerine dayanılarak oluşturulmuş ÖGÖ’ler, kaynaştırma yoluyla eğitim ve müzik ilişkisi, şarkı ve çalg1 eğitimi ile ilgili tezler, akademik dergiler/makaleler ve diğer yayınlar incelenmiştir. Araştırılan konuyla ilgili çalışmaların çok sınırlı sayıda olduğu, bu çalışmaların genellikle müzik alanından ziyade özel eğitim ağırlıklı olarak okul ve benzeri eğitim ortamlarında öğrencilere çeşitli alana özgü teknik uygulamalar ve denemeler yapılması yönünde olduğu, çeşitli öğretim yöntemlerinin müzik aracılığ 1 ile kullanılarak test edilmesi, bazılarının ise karşılaştırmalı çalışmalar şeklinde veriler elde etmiş olan araştırmalar olduğu belirlenmiştir.

\section{Araştırma modeli}

Sonuçları ile var olan bir durumu ortaya çıkarma amacında olan bu araştırma nitel bir durum tespiti-tarama çalışması olarak değerlendirilebilir. Ersoy ve Yalçınoğlu'na (2012) göre durum çalışması katılımcı gözlemleri ve ayrıntılı görüşmelerle dokümanlar toplama, bunların ayrıntılı analiz edilmesi ve boyutsal olarak değerlendirilmesidir. Büyüköztürk, Çakmak, Akgün, Karadeniz ve Demirel'e (2009) göre betimsel araştırma, araştırılan durumun olabildiğince ayrıntılı yani tam olarak tanımlandığı ve eğitim alanında en yaygın kullanıldığı bilinen araştırma çeşididir. Bu tür araştırmalarda araştırmacılar yetenek, tercih, davranış, başarı durumları, tutumlar gibi birey ve grupları ilgilendiren konular ile okul gibi somut eğitim ortamlarının özelliklerini inceleyebilirler. 


\section{Çalışma grubu}

Evreni Bolu ilinde kaynaştırma yoluyla eğitim vermiş tüm müzik öğretmenleri olan bu çalışmanın örneklem grubu Bolu ili merkez ilçesinde 2013-1014 Eğitim-Öğretim y1lında görev yapmakta olan kaynaştırma yoluyla eğitimi vermiş veya vermekte olan 9 ilköğretim okulundaki 10 müzik öğretmenidir. 10 öğretmenin gerçek isimleri değil temsili isimler kullanılmıştır. İçerik analizi tablolarında katılımcılar sütununda öğretmenlerin temsili isimlerinin baş harfleri yazılmıştır. $\mathrm{M}$ harfi ile başlayan iki farklı isim kullanıldığı için bu katılımcılar M ve M2 olarak kodlanmıştır.

Tablo 1.

Katılımc1 Müzik Öğretmenlerinin Demografik ve Mesleki Özellikleri

\begin{tabular}{|c|c|}
\hline $\begin{array}{l}\text { Demografik-Mesleki Özellikler ve } \\
\text { Sorular }\end{array}$ & Cevaplar \\
\hline Cinsiyet & 8 Kadın, 2 Erkek \\
\hline Medeni durum & 9 Evli, 1 Bekar \\
\hline Lisans mezuniyet okul türü & $\begin{array}{l}\text { Tüm katılımcılar Eğitim Fakültesi Müzik } \\
\text { Öğretmenliği Bölümü mezunudur. }\end{array}$ \\
\hline Lisans mezuniyet y1lları & $\begin{array}{l}\text { Katılımcılar 2000-2009 yılları arasından mezun } \\
\text { olmuşlardır }\end{array}$ \\
\hline Lisansüstü eğitim durumları & 2 katılımcı yüksek lisans mezunudur \\
\hline Kaynaştırma eğitimi verdikleri yıl & 2-14 yıl arasında değişmektedir. \\
\hline Şu an çalıştıkları kul kademesi & $\begin{array}{l}\text { Tüm katılımcılar ortaokul kademesinde } \\
\text { çalışmaktadır }\end{array}$ \\
\hline $\begin{array}{l}\text { Kaynaştırma yoluyla eğitim verdiğiniz } \\
\text { sınıfın özelliği }\end{array}$ & 2 katılımcı özel sınıfta, 8 katılımcı birleşik sınıfta \\
\hline $\begin{array}{l}\text { Kaynaştırma yoluyla eğitim verdiğiniz } \\
\text { ortam }\end{array}$ & $\begin{array}{l}9 \text { katılımcı okulda bir sınıf, } 1 \text { katılımcı öğrencinin } \\
\text { evinde }\end{array}$ \\
\hline $\begin{array}{l}\text { Şimdiye kadar kaynaştırma yoluyla } \\
\text { eğitimi verdiğiniz öğrencilerin sınıf } \\
\text { seviyeleri }\end{array}$ & $\begin{array}{l}\text { Tüm katılımcılar 4, 5, 6, 7, 8. sınıf seviyelerindeki } \\
\text { öğrencilerle çalışmışlardır. }\end{array}$ \\
\hline Okulda kendinize ait bir müzik dersliği & $\begin{array}{l}4 \text { katılımcının müzik dersliği var, } 6 \text { katılımcının } \\
\text { müzik dersliği yok }\end{array}$ \\
\hline $\begin{array}{l}\text { Şu an kaynaştırma yoluyla eğitimi } \\
\text { verdiğiniz öğrenci sayısı }\end{array}$ & $\begin{array}{l}\text { Katılımcıların şu eğitim verdikleri kaynaştırma } \\
\text { öğrencilerinin sayısı 2-8 arasındadır. }\end{array}$ \\
\hline $\begin{array}{l}\text { Kaynaştırma öğrencisi olan sınıfların } \\
\text { ögrenci mevcutlarının en az, en çok ve } \\
\text { ortalama sayıları }\end{array}$ & En az 16 , ortalama 28 , en fazla 40 \\
\hline $\begin{array}{l}\text { Katılımcıların özel eğitim alanında } \\
\text { herhangi bir seminer, sertifika } \\
\text { programı, proje, kurs vb ne katılma } \\
\text { durumları }\end{array}$ & 2 öğretmen katılmıştır, 8 öğretmen katılmamıştır. \\
\hline $\begin{array}{l}\text { Katılımcıların şimdiye kadar } \\
\text { edindiğiniz deneyimlere dayanarak } \\
\text { kaynaştırma öğrencilerinize müzik } \\
\text { derslerinde uygulayabildikleri öğretim } \\
\text { yöntemlerine verdikleri yanıtlar }\end{array}$ & $\begin{array}{l}\text { Anlatım, uygulama, gösterip yaptırma, çalıp } \\
\text { söyleme, yansıtma, drama, yaparak yaşayarak } \\
\text { öğrenme, kulaktan öğretim, toplu söyleme, } \\
\text { ritimleme, Orff çalgıları ile şarkı öğretimi, } \\
\text { renklerle notaların ayrımı (bazı öğrencilerde), } \\
\text { tartışma, soru-cevap, doğrudan öğretim, sunum. }\end{array}$ \\
\hline $\begin{array}{l}\text { Şu an görev yaptığınız okulda bulunan } \\
\text { kaynaştırma öğrencilerinin yetersizlik } \\
\text { durumları nelerdir }\end{array}$ & $\begin{array}{l}\text { İşitme yetersizliği, fiziksel yetersizlik, ortopedik- } \\
\text { süreğen hastalık, konuşma yetersizliği. }\end{array}$ \\
\hline $\begin{array}{l}\text { Çalıştıkları okulda rehberlik } \\
\text { öğretmeninin olup olmama durumu }\end{array}$ & 6 okulda var, 3 okulda yok \\
\hline
\end{tabular}




\section{Verilerin toplanması}

Araştırmanın verileri öğretmenlerin görev yaptıkları okullarda bizzat araştırmacılar tarafindan öğretmenlere uygulanmış olan yarı yapılandırılmış görüşme formu ile elde edilmiştir. Büyüköztürk ve diğerlerine (2009) göre nitel araştırmalarda genellikle araştırmacı gözlemcidir. Bilgiyi doğrudan kaynağından alma düşüncesini savunan gözlemci araştırmacılar elde etmek istedikleri veriler için zamanı uzunca kullanırlar. Zengin içerikli tanımlamalar yapmak amaçlarıdır ve bu tanımlar-anlatımlar sayısal ifadeler kullanılarak yapılmaz. Nitel araştırmaların önemli amaçlarından birisi sonuçları önyargısız biçimde ve katılımcıların görüşlerini doğru yansitarak sunmaktır.

\section{Veri toplama aracı}

Araştırma verileri, genellikle nitel araştırma yöntemlerinde kullanılan ve araştırmacılar tarafından geliştirilmiş olan yarı yapılandırılmış görüşme formu ile elde edilmiştir. Görüşme formu, hem sabit seçenekli cevaplamaları hem de araştırma ile ilgili alanda derinlemesine bilgiye ulaşmaya çalışan formlardır (Büyüköztürk ve diğerleri, 2009). Görüşme formunun oluşturulmasında öncelikle gerekli literatür incelenmiş, müzik eğitim-öğretim program ve planları gözden geçirilmiş, özel eğitim-kaynaştırma yoluyla eğitim ve müzik, ÖGÖ'ler ve müzik ilişkili eğitim öğretim planlarına ulaşılmaya çalışılmıştır. Bu incelemeler sonrasında görüşme formunun ana başlıkları genel müzik eğitimi, şark1 eğitimi ve çalg1 eğitimi olarak düzenlenmiştir. $\mathrm{Bu}$ başlıklarda araştırma okullarındaki durum gözden geçirilmiş ve "katılıyorum", "katılmıyorum" olarak iki şıklı ve bazıları da açık uçlu olmak üzere görüşme soruları hazırlanmıştır. Bu sorular araştırma alanı ile ilgili beş alan uzmanı (müzik ve özel eğitim) akademisyen tarafından incelenmiş ve yapılan gerekli düzeltmeler ile son halini almıştır. Görüşme formunun başında mesleki ve demografik özelliklerin tespiti için çeşitli sorular da mevcuttur. Sevinç'e (2011) göre açık uçlu sorular; bilinmeyenleri ortaya çıkarmaktan yola çıkarak kişilerin görüşlerini ayrıntılı incelemek amacındadır.

\section{Verilerin Analizi}

Görüşme formunda "katıliyorum" ve "katılmıyorum" şeklinde yer almış olan soruların yüzdelik dilimlerine bakılmıştır. Müzik öğretmenlerinin açık uçlu sorulara verdikleri cevapları ise "içerik analizi” yöntemi kapsamında tüme varım tekniği kullanılarak ayrı ayrı çözümlenmiş ve değerlendirilmiştir. Bu aşama öğretmenlerin fikir yazılarını inceleme, genel başlıklar oluşturma, yakın-yoğun görüşleri düzenleme, gruplamalar yoluyla birleştirme, farklı düşünceleri tespit etme ve varsa onların da çokluk-sıklık durumlarına göre bütünleştirilmesini sağlama olarak görülebilir. Katılımcıların sayısı ile ilişkili olarak "katılıyorum" ya da "katılmıyorum" şeklindeki cevaplarından yola çıkarak da çoğunluk, azlık, yarısı, büyük çoğunluk, çok azı gibi tanımlamalar ile o soru ile ilgili genel eğilime ulaşılmaya çalışılmıştır.

Betimsel ve sistematik analizlerde araştırmacı görüşme sonrasında edinilen metinleri sinıflandırır ve yorumlar (Demir, 2011, 301). Araştırmada toplanan veriler araştırma problemine yönelik kuramsal ya da pratik çözüm önerileri geliştirebilmesi yönünde işlenerek çözümlenir, yorumlanıp değerlendirilir (Karasar, 2009). Nitel araştırmalarda soruların cevaplandırılmasında ya da hipotezlerin test edilmesinde istatistiksel yöntemler kullanılmaz. Sayısal değerler değil betimlemeler mevcuttur (Büyüköztürk ve diğerleri, 2009). Görüşme formundaki mevcut olan ve açık uçlu fikirleri ortaya çıkarmayı amaçlayan sorulara verilen cevaplar dikkatle incelenmiş, cevaplarla ilgili temalar-motifler belirlenmiş ve belirlendikten genel görüşü ortaya çıkardığı varsayılan özet bulguya ulaşılmış ve ifadelendirilmiştir. Elde edilen bulgular ile şark1 eğitimi ve çalgı eğitimi arasında ilişkiler araştırmanın problemi kapsamında incelenmiş ve betimsel sonuçlara ulaşılmıştır. Elde edilen bulgu ve sonuçlar alan uzmanları tarafindan incelenmiş ve gerekli düzeltme-onaylama çalışmalarından sonra bulgular son halini almıştır.

Nitel veri analizinin üç temel aşaması:

a) Verilerin düzenlenmesi: Konu hakkında kategori ve temaları belirlenmesi için göze çarpan kelimeler, cümleler ve olaylar şablonlarla kodlanır. Bu kodlar verileri düzenlerken kategoriler olarak kullanılır. Elde edilen kodların bir kısmı alt düzey kodlar 
olarak ele alınabilir. Veriler kodlanırken birbirleri ile yakın ilişkili olanlar bir araya getirilir.

b) Verilerin özetlenmesi: Düzenlenen verilerin özetlenmesi gerektiğinden dolayı özetleme aşamasında kategorilerdeki bilgiler incelenir ve bu bilgilerin özünü yansitan bir ya da iki cümle yazılır.

c) Veriler kodlanıp özetlendikten sonra kategoriler arasındaki ilişkilerden yola çıkılarak genellemelere gidilir. Araştırmacı bulguları tümevarım yöntemi ile yorumlar ve sonuçları şekillendirmiş olur (Büyüköztürk ve diğerleri, 2009).

\section{Bulgular ve Yorumlar}

\section{Şarkı eğitimine ilişkin bulgular ve yorumlar}

Görüşme formundan elde edilen şarkı eğitimi kategorisine ait bulgular aşağıda açıklanmış ve bulgularla ilgili yorumlar yapılmıştır.

Soru 1: "Kaynaştırma öğrencilerim çeşitli nedenlerden dolayı şarkı eğitimi performanslarına yeterli katılımı sağlayamamaktadır" ifadesine katılımcıların hepsi de (\% 100) kaynaştırma öğrencilerinin şarkı eğitimi performanslarına yeterli katılımı sağladıklarını belirtmişlerdir. Katılımcıların hepsinin bu soruya aynı şekilde cevap vermiş olmaları nedeniyle kaynaştırma öğrencilerinin şarkı söyleme performansı göstermede aktif ve istekli oldukları düşüncesine, şarkı eğitiminin becerilebilme-başarılabilme açısından çalg1 eğitimi kategorisine nazaran daha basit ve bu sonuca göre daha çok sevildiği, öğrencilerin bu nedenlerle şarkı söylemeye etkili yönlendikleri/katıldıkları düşüncesine ulaşılabilir.

Soru 2: "Kaynaştırma öğrencilerim şarkı eğitimi alıştırmalarında ve şarkılarda hız ve nüans terimlerini uygulayamamaktadırlar" ifadesine katılımcıların yarısı (\%50) kaynaştırma öğrencilerinin şark1 eğitimi alıştırmalarında ve şarkılarda hız ve nüans terimlerini uygulayabildiklerini diğer yarısı da (\%50) uygulayamadıklarını belirtmişlerdir. Hız terimleri ve nüanslar müzikal dinamiklerin önemli ve üst seviye de bir uygulama pratiği-sunumu özelliğinde olduğu için katılımcılardaki bu görüş farklılığının öğretmenin öğretme teknikleri, öğrencinin ilgisi ve zihinsel kapasitesi, öğretilecek olan şark1 ve sözleri, öğrencinin okuma yazma kabiliyeti ve hafizası ile doğrudan ilgili ve ilişkili olduğu düşünülebilir. Bu düşüncelerin bulgunun bu şekilde çıkmasına da yön vermiş olduğu düşünülmektedir.

Soru 3: "Şarkı eğitimi sırasında drama ve oyunlaştırılmış etkinlikler kullandığımda kaynaştırma öğrencilerimin derse olan ilgisi ve şarkı söylemeye katılımları artabiliyor" ifadesine katılımcıların hepsinin (\%100) katılıyorum şeklinde cevap verdikleri tespit edilmiştir. Bu bulgudan yola çıkarak şarkı eğitiminde eğlence, eğlendirici ek uygulamalar ve hareket arttıkça ilginin arttığı, öğrencilerin daha aktif katılımlarda olabilecekleri öğretim teknikleri kullanılma durumlarında derse ilginin belirgin biçimde arttı̆̆ düşünülebilir. Drama, masal, hikâye canlandırmaları, basit ritim çalgıları kullanımı, şarkı sözleri aracılığıyla okuma-yazma pratikleri sayesinde şarkı eğitiminin ve etkinliklerinin cazip ve çekici duruma gelmekte olduğu söylenebilir. Çakır Doğan (2011)'e göre ÖGÖ’ler için müzik dersinde ritim, ses çalışmaları, şarkı söyleme, dans ve oyunlar, müzikli öykü ve drama uygulamaları yapılabilecek başlıca uygulamalardır. Sadece ders içinde uygulanmaması gereken bu etkinlikler ders dişı etkinliklerde de kullanılmalı ve bu etkinliklerin uygulaması oyunlaştırma yoluyla yapılmalıdır (8-9).

Soru 4: "Kaynaştırma öğrencilerim şarkıların sözlerini yeteri kadar ezberleyebiliyorlar" ifadesine katılımcıların çoğunluğunun kaynaştırma öğrencilerinin şarkıların sözlerini yeteri kadar ezberleyebildiklerini belirttikleri görülmüştür (\% 70 katılıyorum \% 30 katılmıyorum). Katılımcı öğretmenlerin şarkı sözlerini ezberletme konusunda çok fazla tekrarla bu sorunu çözülebildikleri fikrine ulaşılabilir. Kaynaştırma öğrencilerinden yüzde yüz başarı beklentisinde olunamayacağı fikri ile ilişkili olarak ve katılımcı öğretmenlerin çoğunluğunun görüşü ile bağlantılı olarak, kaynaştırma öğrencilerinin eğitim ortamında ellerinden geldiğince aktif katılımda bulunmaları için uğraşmaları müzik öğretmenlerinin özverili çalışmalar yaptığı fikrini ortaya çıkarabilmektedir.

Soru 5: "Kaynaştırma öğrencilerim sınıfta bireysel olarak şarkıları seslendirebiliyorlar" ifadesine katılımcıların büyük çoğunluğu kaynaştırma öğrencilerinin sınıfta bireysel olarak 
şarkıları seslendirebildiklerini belirtmişlerdir (\% 80 katılıyorum \% 20 katılmıyorum). Bu bulguya göre kaynaştırma öğrencilerinin çekinerek de olsa bireysel olarak şark1 söyleyebildikleri, söylenecek şarkıyı iyi öğrenmiş olabilmelerinin de etkisi düşünülerek tam olmasa da yeteri kadar performans gerçekleştirebildikleri fikrine ulaşılabilir. Ayrıca katılımcı öğretmenlerin kaynaştırma öğrencilerinin bireysel şarkı söyleme performanslarına kendi istekleri ile katıldıkları genel görüşüyle de ilişkili olarak öğrencilerin bireysel performanslardan kaçınmadıkları, müzik derslerinde kendilerini müzik sınıfı sosyal ortamlarında sunmaktan çekinmedikleri söylenebilir.

Soru 6: "Kaynaştırma öğrencilerimin şarkı performanslarının çalgı performanslarına göre daha iyi durumda olduğunu düşünüyorum" ifadesine katılımciların neredeyse tümü katılıyorum şeklinde cevap vermişlerdir (\% 90 katılıyorum \% 10 katılmıyorum). Katılımcıların kaynaştırma öğrencilerinin çalgıya ve eğitimine olumsuz önyargı içinde olabilecekleri ve kaynaştırma öğrencileri için çalgı performansının/eğitimlerinin daha karışık fiziksel-zihinsel birliktelik gücü ve çalışma/pratiği gerekliliğinden dolayı bu düşüncede oldukları düşünülebilir. Katılımcı öğretmenlerin kaynaştırma öğrencilerinin çalg1 eğitimine nazaran şarkı eğitimlerinde daha başarılı performanslar göstermesi tabi ki bu öğrencilerin zor olandan kaçtıklarını ortaya çıarmaz. Fakat hassas özelliklerinden dolayı kaynaştırma öğrencilerinin çalg1 eğitimindeki fiziksel, zihinsel ve duygusal bağın yeterince kurulamaması normal bir durum olarak karşılanabilir.

Soru 7: "Kaynaştırma öğrencilerim şarkıların sözlerini sınıfla birlikte takip edebiliyorlar" ifadesine katılımcıların büyük çoğunluğunun katılıyorum şeklinde cevap verdikleri tespit edilmiştir (\% 80 katılıyorum \% 20 katılmıyorum). Kaynaştırma öğrencilerinin şark1 sözlerini sınıftaki arkadaşları söylerken onlardan geri kalmadan, arkadaşlarıyla birlikte takip edebilmelerinin okuma ve yazma kabiliyetleri ile doğrudan ilişkili olduğunu akla getirebilir. $\mathrm{Bu}$ bakımdan bu bulgu katılımcı öğretmenlerin eğitim verdikleri kaynaştırma öğrencilerinin okuma yazma konusunda problemleri olmadığı ve ayrıca şarkı sözlerinin çalıştırılmasında sıkıntı yaşamadıkları şeklinde yorumlanabilir.

Soru 8: "Genel başarılarının düşük olmasından dolayı sınıfta ortaklaşa söylenecek olan şarkıların seçiminde kaynaştırma öğrencilerimin durumlarını dikkate alamıyorum" ifadesine katılımcıların neredeyse hepsinin katılıyorum şeklinde cevap verdikleri belirlenmiştir (\% 90 katılıyorum, \% 10 katılmıyorum). Kaynaştırma öğrencilerinin normal gelişim gösteren arkadaşları ile aynı ortamlarda eğitim almaları gerektiği bilinciyle müzik öğretmenlerinin de doğal olarak sınıflarında sayıları genelde bir ya da iki tane olabilen kaynaştırma öğrencilerini dikkate alamamış olabilecekleri düşünülmektedir. Bir müzik dersi saati içinde kaynaştırma öğrencisi olan ve normal gelişim gösteren öğrencilerin özelliklerine göre iki farklı şarkı öğretimi yapılmasının zaman ve teknik açıdan çok zor olmasından dolayı müzik öğretmenlerinin çoğunlukta olan ve normal gelişim gösteren öğrencilere yönelik şarkı seçimi yapmalarının öğretmenlerin zorunlu kaldıkları bir durum olduğu düşünülebilir.

Soru 9: "Kaynaştırma öğrencilerim güncel ve popüler şarkılara daha fazla ilgili göstermekte ve başarılı olabilmektedirler" ifadesine katılımcıların büyük çoğunluğu katılıyorum şeklinde cevap vermişlerdir (\% 80 katılıyorum, \% 20 katılmıyorum). Popüler kültür ürünü olan şarkıların kolay sözleri ve basit akılda kalıcı ezgilerinin kaynaştırma öğrencilerinin şarkı eğitimine katılımlarını kolaylaştırmada olumlu etkisi olabildiği düşünülmektedir.

Soru 10: "Kaynaştırma öğrencilerimin az bir bölümü: 0, yarısı: 2, çoğunluğu: 8 şark1 eğitimlerinde yeteri kadar başarılıdırlar" boşluk doldurma şeklinde sorulmuş olan katılımcıların büyük çoğunluğunun kaynaştırma öğrencilerinin şarkı eğitimlerinde yeteri kadar başarılı olduklarına inandıkları tespit edilmiştir. Katılımcı öğretmenlerin büyük çoğunluğu tarafindan şarkı eğitiminde kaynaştırma öğrencilerinin başarılı görülmesinde müzik öğretmenlerinin uyguladıkları çeşitli uygulamaların, ilgilerini yüksek tutma girişimlerinin ve onları derse eğlenceli etkinliklerle kanalize etmelerinin faydası ve olumlu etkisinin olabildiği düşünülmektedir. 
Soru 11: "Şarkı öğretimi için kaynaştırma öğrencilerinize programda yer alan müzik dersinden başka özel bir çalışma zamanı uygulayıp uygulayamama durumunuz hakkında görüşleriniz nelerdir?" sorusuna ilişkin analizler Tablo 2'de sunulmuştur.

Tablo 2.

Şarkı Öğretimi İçin Kaynaştırma Öğrencilerine Programda Yer Alan Müzik Dersinden Başka Özel Bir Çalışma Zamanı Uygulayıp Uygulayamama Durumu

\begin{tabular}{clc}
\hline Tema & \multicolumn{1}{c}{ Kod } & Katılımcılar \\
\hline Programlar & Bep' te yer almışsa, & B, M \\
Zaman & Dersi olmadığı boş saatlerde, & Ç,Ö, A \\
Gereklilik & Yeterli oranda başarılılar & G \\
Kurs ve Okul Dışı Çalışmalar & Okulda açılan kurslarda & S, M \\
Dış Etkenler & Taşımalı okul & Ç, F \\
\hline
\end{tabular}

Soruya ilişkin verilmiş cevaplarda az sayıda katılımcıların öğrencinin BEP'in de yer verilmesi durumunda ek çalışma zamanı uyguladıkları ve bundan başka okul dışında mevcut olan kurslarda çalışmalar yapıldığı belirtilmiştir. Buna neden olarak katılımcıların büyük çoğunluğu mesai saatleri içerisinde öğrenciler için ek bir çalışma zamanının ayrılmasının mümkün olmadığını, bazı katılımcıların okullarında taşımalı eğitim yapıldığını ve bunun programlama sıkıntısı yarattığını ve bazıları da okuldaki ders programlarının ek çalışma zamanlarına uygun olmadığını belirtmişlerdir. Böylelikle katılımcı öğretmenlerin ellerinde olmayan sebeplerle ek çalışma sürelerini yeterince uygulayamadıkları anlaşılabilmektedir. Bu durum hem kaynaştırma öğrencileri için ve hem de normal gelişim gösteren öğrenciler için geçerli bir olumsuzluk olarak kabul edilebilir.

Soru 12: "Kaynaştırma öğrencilerinizi de düşünerek sınıfta ortaklaşa seslendirilecek olan şarkıların seçiminde şarkı sözlerinin anlatmak istediği genel anlama ilişkin dikkat ettiğiniz noktalar nelerdir?" sorusuna ilişkin analizler Tablo 3'de sunulmuştur.

Tablo 3.

Kaynaştırma Öğrencilerinin De Düşünülerek Sınıfta Ortaklaşa Seslendirilecek Olan Şarkıların Seçiminde Şark1 Sözlerinin Anlatmak İstediği Genel Anlama İlişkin Dikkat Edilen Noktalar

\begin{tabular}{llc}
\hline Tema & Kod & Katılımcılar \\
\hline Anlam incelemesi ve takibi & Öğrencilere anlam sorma & $\mathrm{S}$ \\
& Belirli gün ve haftalara uygunluk & $\mathrm{C}$ \\
& Özel gereksinimini hatırlatmayan konuda olan & $\mathrm{G}$ \\
& Net anlatımı olan ve dolaylı anlatımı olmayan & $\mathrm{F}$ \\
& Özel eğitim sınıfında somut anlamlı kelimeler & Ö \\
& Sinıf seviyesi & B, M, I \\
Bireysel Farklılık & Kişisel farklılıklarla ilişki & $\mathrm{A}$ \\
& Çok hızlı olmamalı & $\mathrm{M}$ \\
Söyleniş & Milli Ĕ̆itim Kitaplarına bağlılık & $\mathrm{B}, \mathrm{M}$ \\
Müfredat-Program-Kitap & & \\
\hline
\end{tabular}

Soruya yapılmış olan yorumlar incelendiğinde öğretmenlerin sınıf seviyesine uygun olan, müfredatla ilişkili olan, varsa kaynaştırma öğrencilerinin engel durumunu onlara hatırlatmayan, mevsimler, belirli gün ve haftalar, temizlik vb gibi herkese hitap edebilecek konusu olan, Orff yöntemi ile ilişkilendirilmeye açık olan, çok hızlı veya çok yavaş olmayan, sözcükleri açısından dolaylı anlatımı olmayan ve anlaşılır fikirli olan şarkıların seçimine dikkat ettikleri tespit edilmiştir. Katılımcı öğretmenlerin gerekli olan etkenleri dikkate alarak şarkı seçimlerini yaptıkları görülebilmektedir. Fakat araştırmanın diğer sorusu olan öğretmenlerin şarkı seçiminde kaynaştırma öğrencilerini dikkate alamamaları durumu ile çelişen bu sorunun 
yorumlarının şekillenmesinde müzik öğretmenlerinin sınıflarında normal gelişim gösteren öğrencilerin çoğunlukta olmasından etkilenerek şarkı seçimlerini yaptıkları fikrinin oluşmuş olabileceği, aynı zamanda kaynaştırma öğrencilerinin şarkı eğitiminde hassas olabilecekleri özelliklerini de bilmelerine rağmen bu özellikleri uygulayamadıkları fikrinde oldukları düşünülmektedir.

Soru 13. "Seçeceğiniz şarkıların kelime yapısı/özelliklerine ilişkin dikkat ettiğiniz noktalar nelerdir?" sorusuna ilişkin analizler Tablo 4'de sunulmuştur.

Tablo 4.

Seçilecek Şarkıların Kelime Yapısı/Özelliklerine İlişkin Dikkat Edilen Noktalar

\begin{tabular}{llc}
\hline Tema & Kod & Katılımcılar \\
\hline Seviye & Öğrencinin anlama yaşı & $\mathrm{S}$ \\
& Sinıf seviyesine uygunluk & $\mathrm{S}$ \\
\multirow{3}{*}{ Ses-hareket ve Bölünmeler } & Çeşitli hareketlerle & $\mathrm{C}$ \\
& ilişkilendirilebilen & $\mathrm{C}$ \\
& Tekrarlı ardıl söylenmeye uygunluk & $\mathrm{S}$ \\
& Mesajının olması & $\mathrm{S}$ \\
& Eğitici-öğretici olması & $\mathrm{A}$ \\
& Güncel yaşamı belirten & Ö \\
Telaffuz ve Lisan & Somut nitelikli & $\mathrm{M}$ \\
& Hizlı söylenişi olmayan & $\mathrm{M}$ \\
& Türkçe olması & $\ddot{O}$ \\
\hline
\end{tabular}

Katılımcılar tarafindan soruya yapılan yorumlar incelendiğinde seviyeye uygunluk, eğitici bir mesaj içermesi, eğitici olması, akılda kalıcılığı kolaylaştıran tekrarlı kolay kelime veya hecelerinin olması, güncel yaşamı hatırlatan özelliklerde olması, somut olması, kolay telaffuzlu olması, yabancı kökenli kelimelerin olmaması, söylenme durumu hılı olmayan yapıda olması gibi noktalara dikkat edildiği anlaşılmıştır. Katılımcı öğretmenler tarafından bu kadar fazla sayıda etkene dikkat edilerek şarkı seçiminin yapılması öğretmenlerin normal gelişim gösteren ve göstermeyen öğrenciler arasındaki farkı bildikleri ve dikkat ettikleri fikrini ortaya çıkarabilmektedir.

Zihinsel yetersizliği olan öğrencilerin müzik derslerinde öğretilecek şarkıların seçiminde şarkı sözlerinin yalın, anlaş1ır ve kültürel değerlerimize uygun, eğitici nitelikte olmasına ve şarkıların öğrencilerin müziksel farkındalık düzeyleri ve ses sınırlarına uygun olmasına dikkat edilmelidir (Çakır Doğan, 2011).

Soru 14. "Kaynaştırma öğrencilerinize şark1 eğitimi verirken varsa sizin özel olarak geliştirdiğiniz bir yöntem, teknik veya uygulama hakkında görüşleriniz?” sorusuna ilişkin analizler Tablo 5 'te sunulmuştur.

Tablo 5.

Kaynaştırma Öğrencilerine Şarkı Eğitimi Verirken Varsa Özel Olarak Geliştirdikleri Bir Yöntem, Teknik veya Uygulamalar

\begin{tabular}{llc}
\hline Tema & Kod & Katılımcılar \\
\hline Öğretim yöntemi & Kulaktan öğretim yöntemi & B,S \\
Vokal & Vokal olarak söyleyip tekrar ettirme & B,M \\
Çalgı kullanımı & Çalgı ile çalma & S \\
& Çalgı ile çalme ve vokal tekrar ettirme & S
\end{tabular}




\begin{tabular}{llc} 
& Çalgı ile eşliğinde söyletme & S \\
Şarkı & Bölümlere ayırarak çalışma & Ö,M \\
Kaynaştırma Öğrencisi ve Çevre & Bireysel öğrenme farklılıklarına dikkat ederek & $\mathrm{M}$ \\
& Rehber öğrenci-Arkadaş eşliğinde öğrenme & $\dot{I}$ \\
\hline
\end{tabular}

Katılımcılar tarafından soruya yapılmış olan yorumlar incelendiğinde klasik öğretme yöntem ve tekniklerinden farklı bir uygulama yapılmadığı anlaşılmıştır. Bu durum katılımcıların büyük çoğunluğunun özel eğitim alanında herhangi bir kurs-seminer-eğitici faaliyete katılmamış olması ile ilişkilendirilebilir. Özel eğitim alanında uygulanmakta olan farklı öğretim yöntem ve yaklaşımları hakkında bilgilerinin yetersizliğinden dolayı bu bilgileri şarkı öğretimine aktaramamış ve yeni uygulamalara erişememiş olma ihtimallerini akla getirebilmektedir.

Soru 15. "Şark1 eğitiminin ve şarkı söylemenin kaynaştırma öğrencilerine olan faydaları sizce neler olabilir?" sorusuna ilişkin analizler Tablo 6'da sunulmuştur.

Tablo 6.

Şark1 Eğitiminin ve Şark1 Söylemenin Kaynaştırma Öğrencilerine Olan Faydaları

\begin{tabular}{llc}
\hline Tema & Kod & Katılımcılar \\
\hline Bilişsel Gelişim & Ezber yeteneklerini geliştiriyor & B \\
Duygusal Gelişim & Utanma duygusu azalıor & B \\
& Kendine güven duygusu artıyor & B,A.M,M2,F,I \\
& Bir işi başarabilme duygusunu ediniyorlar & S,A,İ \\
& Psikolojik olarak rahatlığa erişiyorlar & Ç \\
& Mutlu oluyorlar & Ç.Ö \\
& Toplumda eşitlik duygusunu kazanır & M2 \\
& Telaffuz gelişimi sağliyor & B \\
Akademik Gelişıim & Kavram öğretimi yapılmış oluyor & Ö \\
& Birlikte iş yapma yeteneği gelişiyor & B,Ö.M2,F,I \\
Sosyal Gelişim & Kendisini fark etme & A \\
& Diğer derslere göre daha eğlenceli faaliyet olarak & S \\
gisiplinlerarası Gelişim & görüyorlar & S \\
& Diğer derslere de katkısı oluyor & M \\
\hline
\end{tabular}

Katılımcılar tarafından yapılmış yorumlar incelendiğinde kaynaştırma öğrencilerinin ezber güçlerinin arttı̆̆ı, telaffuzlarının geliştiği, utanma-çekinme gibi duyguların azaldığı, güven duygularının arttı̆̆ duygusunun oluştuğu, diğer derslerdeki başarılarına da faydası olduğu, rahatladıkları, mutlu oldukları, grupla çalışma becerilerinin geliştiği ve sosyalleştikleri yönünde olduğu anlaşılmaktadır. Katılımcı öğretmenlerin bu derece güçlü izlenimleri olması kaynaştırma öğrencilerine verdikleri şarkı eğitimlerindeki ciddiyet seviyesinin olumlu anlamda yüksek olduğunu gösterebilmektedir.

Soru 16."Konuşma engeli olan veya konuşmada zorlanan kaynaştırma öğrencileriniz için özel bir uygulama yapıyor musunuz?" sorusuna katılımcıların sadece yarısı kısa cevaplar vermişlerdir. Bu kısa cevaplar içerik analizi boyutuna alınması için yeterli olmadıklarından cevap veren öğretmenlerin görüşleri genel olarak özetlenmiştir. Yapılan yorumlar incelendiğinde bazı öğretmenler konuşma engeli olan veya konuşmada zorlanan kaynaştırma öğrencileri olmadığını, olanlar ise ders içinde bu öğrencinin psikolojik olarak rahat konumda olmaları için özen gösterdiklerini, rahat davranışlara ulaşırlarsa konuşmalarının daha anlamlı olduğunu belirtmişlerdir. Bu soruyla ilişkili olarak özel eğitim konusunda yeterli bilgi ve 
deneyime sahip olmadıklarını belirtmiş olan bir grup katılımcı öğretmenin konuşma yetersizliği gibi ek yetersizlikleri olan öğrencilerinin olması durumlarında nasıl uygulamalar yapabilecekleri hususunda eksiklikleri olduğunu belirtmişlerdir.

\section{Çalgı eğitimine ilişkin bulgu ve yorumlar}

Görüşme formundan elde edilen çalgı eğitimi kategorisine ait bulgular aşağıda açıklanmış ve bulgularla ilgili yorumlar sunulmuştur.

Soru 1: "Kaynaştırma öğrencilerim çeşitli nedenler yüzünden çalgı eğitimi performanslarına yeterli katılımı sağlayamamaktadır" ifadesine katılımcıların büyük çoğunluğu (\%80 katılıyorum ve \%20 katılmıyorum) yönünde cevap vermişlerdir. Çalg1 eğitiminin şark1 eğitimine göre daha zor ve karışık becerileri içermesi, normal gelişim gösteren öğrencilerle bile sık tekrarlar yapılmasının gerekliliği ve bu sayının kaynaştırma öğrencileri için daha da artabilmesi gibi nedenlerle kaynaştırma eğitimi öğrencilerinin büyük çoğunluğunun çalg1 eğitimi ve performanslarına katılmak istemeyebilecekleri akla gelen ilk nedenler olabilir.

Soru 2: "Kaynaştırma öğrencilerim çalgı eğitimi alıştırmalarında ve çalg1 eserlerinde hız ve nüans terimlerini uygulayamamaktadırlar" ifadesine katılımcıların büyük çoğunluğunun (\% 80 katılıyorum \% 20 katılmıyorum) katıldı̆̆ 1 tespit edilmiştir. Bir eserin teknik olarak ele alınarak bütünü ile çalışıldıktan sonra ezber aşamasından bir önceki aşama hız ve nüans bakımından ele alınarak çalışılması sürecidir. Kaynaştırma öğrencilerinin bir eseri doğru veya yeterli hızda çalabilmesi için yeterli teknik ve teorik kazanımı elde etmiş olmaları gerekmektedir. Bu aşamayı tamamlama açısından belirli yeterliğe sahip olamamaları öğrencileri bu yeterlikten uzaklaştırarak bu bulgunun çıkmasına neden olmuş olabilir. Ayrıca bir eserde doğru ve yeterli hıza ulaşabilmek için sayıca fazla defa tekrar edilmesi bir gereklilik olabilir. Bu gerekliliğin de çalgı çalma süreçlerinde olumsuz tutumlar yarattığı söylenebilir. Nüanslı performans süreci ise tüm bu yetkinlikler bittikten sonraki yorumlama durumlarının başlangıç aşaması sayılabilir. Basit de olsa eserlerin çoğunluğunda nüans terimleri belirtilmiştir ve uygulanması gereklidir. Eserler nüanslı bölümlerine uygun olarak kısım kısım çalışılmalıdır. Bu süreçte kaynaştırma öğrencileri ile sık ve sayıca çok eser tekrarı yapılmalıdır ve uzun çalışma ve pratik süreçleri gerektirmektedir. Bu durumlar öğrencilerin eserlerdeki hız ve nüansli çalışmalarda kendilerini eserden çekerek başarıyı yakalayabilme konusunda yetersizlikler yaratabilir.

Soru 3: "Çalgı eğitimi sırasında drama ve oyunlaştırılmış etkinlikler kullandığımda kaynaştırma öğrencilerimin derse olan ilgisi ve çalgı çalma etkinliklerine katılımları artabiliyor" ifadesine katılımcıların büyük çoğunluğunun ( $\% \quad 80$ katılıyorum $\% \quad 20$ katılmıyorum) katılıyorum şeklinde cevap verdikleri görülmüştür. Bu sonuçla birlikte katılımcı öğretmenlerin büyük çoğunluğunun kaynaştırma öğrencilerinin çalg1 eğitimine etkin katılmaları için çeşitli çözümleri fark edebilmiş ve şarkı eğitimine oranla daha az da olsa çalgı eğitimine öğrencilerini adapte edebilmekte oldukları düşünülmektedir.

Soru 4: "Kaynaştırma öğrencilerim müzik eserlerinin notalarını veya konuya ilişkin çalışma sayfalarını diğer arkadaşlarıyla birlikte takip edebiliyorlar" ifadesine katılımcıların yarısından fazlasının (\% 60 katılıyorum \% 40 katılmıyorum) şeklinde görüş belirttikleri görülmüştür. Bu bulguya göre kaynaştırma öğrencilerinin arkadaşları ile birlikte nota ve çalışma sayfalarını takip etmede zorlandıkları anlaşılabilmektedir. Çalgı müziği eser ve çalışmalarında birlikteliğin sağlanabilmesi için öğrenilme zorunluluğu olan notalar ve bunların takipleri kaynaştırma öğrencileri için hatta normal gelişim gösteren öğrenciler için bile güç bir beceri olduğu göz ardı edilemeyecek bir durum olarak düşünülebilir. Yeterli öğrenebilmek için ek çalışma saatleri, bireysel destek gibi özel çalışmalar gerekmektedir. Fakat katılımcı öğretmenlerin ek çalışma zamanı ayıramadıkları diğer sorularda verdikleri cevaplardan anlaşılabilmektedir. Bu durumun kaynaştırma öğrencilerinin müzik ve çalgı eğitimlerine kazanımlar sunma açısından önemli bir olumsuzluk olduğu düşünülmektedir.

Soru 5: "Kaynaştırma öğrencilerim çalgı eserlerin notalarını yeteri kadar ezberleyebiliyorlar" ifadesine katılımcı öğretmenlerin yarısının (\%50) katıldığı, yarısının da katılmadığı (\% 50) tespit edilmiştir. Kaynaştırma öğrencileri öğrenme ve akılda tutma, hafızaya 
kayıt etme veya hatırlama konularında yetersizlikleri olabilen öğrencilerdir. $\mathrm{Bu}$ bakımdan kaynaştırma öğrencilerinin çalgı eserlerinin notalarını ezberleyememeleri aslında normal bir durum sayılabilir.

Soru 6: "Kaynaştırma öğrencilerim sınıfta bireysel olarak çalg1 çalabilmektedirler" ifadesine katılımcıların yarısından fazlası (\% 60 katılıyorum \% 40 katılmıyorum) kaynaştırma öğrencilerinin sınıfta bireysel olarak çalgı çalabilme durumları hakkında başarılı olduklarını belirtmiş̧lerdir. Fakat katılımcıların yarısına yakını ise katılmadıklarını belirtmişlerdir. Çekingenlik, yapamama-becerememe, küçük düşme korkusu kaynaştırma öğrencilerinin çalg1 çalma performanslarını yeterince bireysel olarak yerine getirememelerinin sebebi olabileceği düşünülmektedir. Normal gelişim gösteren öğrencilerde dahi görülebilecek bir durum olan çekingenlik ve grup içinde aktivitelere katılımı kaynaştırma öğrencileri açısından düşünüldüğünde daha da alt-yetersiz başarı performansları oluşturabilmesinin normal karş1lanabilecek bir durum olabileceği düşünülmektedir.

Soru 7: "Kaynaştırma öğrencilerimin az bir bölümü:3 yarısı:5, çoğunluğu: 2 çalg1 eğitimlerinde yeteri kadar başarılıdırlar" boşluk doldurmalı ifadede katılımcı öğretmenlerin cevabının ağırlıklı olarak kaynaştırma öğrencilerinin yarısının başarılı olduğu noktasında toplandığ 1 görülebilmektedir. Şarkı eğitimindeki değerlendirme ile ve çalg1 eğitimi bölümünün diğer bulguları ile kıyaslandığında çalgı eğitiminin kaynaştırma öğrencileri için daha karmaşık bir eğitim süreci olduğu düşünülebilir bir durum olmaktadır. Bu duruma sebep olarak çalgı eğitiminin şarkı eğitimine göre daha farklı ve karışı zihinsel, motor, görsel ve fiziksel süreçlerle ilişkili olması gösterilebilir.

Soru 8: "Sınıfta verdiğiniz müzik eğitiminden önce her hangi bir çalg1 eğitimi almış olan veya çalmakta olan kaynaştırma öğrenciniz var mı?” sorusuna katılımcıların hepsi (\% 100) kendi verdikleri çalg1 eğitimlerinden önce çalg1 eğitimi almış olan ve çalg1 çalan öğrenci olmadığını belirtmişlerdir. Ailenin sosyal-kültürel-sanatsal faaliyetlere bakış yaklaşımı, yaşadıkları çevre imkanları, öğrencinin çalgı eğitimi almasını engelleyebilecek yetersizlikgereksinim durumu, öğrencinin yeterli motive edilemeyişi-isteksizliği, deneyimli-istekli öğreticinin bulunamaması gibi çeşitli ve daha da artırılabilecek nedenlerin bulgunun bu şekilde çıkmasında etkili olabileceği düşünülmektedir.

Soru 9: "Çalgı eğitimi için kaynaştırma öğrencilerinize programda yer alan müzik dersinden başka özel bir çalışma zamanı uygulayıp uygulayamama durumunuz hakkında görüşleriniz" sorusuna ilişkin analizler Tablo 7'de sunulmuştur.

Tablo 7.

Çalg1 Eğitimi İçin Kaynaştırma Öğrencilerinize Programda Yer Alan Müzik Dersinden Başka Özel Bir Çalışma Zamanı Uygulayıp Uygulayamama Durumu

\begin{tabular}{llc}
\hline Tema & Kod & Katılımcılar \\
\hline \multirow{2}{*}{$\begin{array}{l}\text { Okul } \\
\text { Program ve çalışma }\end{array}$} & yok & Ç,F \\
& $\begin{array}{l}\text { Haftalılı okul olduğu için okul saatleri dışında şansım } \\
\text { Mesai saatleri içinde boş vakit bulunca ilgilenebilirim }\end{array}$ & B, S, Ö,M2 \\
& $\begin{array}{l}\text { Nöbet günlerimde uygulayabilirim } \\
\text { Öğrencilerin ve benim programımda boş saatler }\end{array}$ & A \\
& uymayabiliyor & Ç \\
& Ders dışı etkinlik çalışma saatlerimde ilgilenebiliyorum & M \\
& Öğrencilerin de programı yoğun olduğu için & S, M2 \\
Öğrenci & yapamıyoruz & S \\
& Yoğun çalışmalar öğrencileri sıkabiliyor & \\
\hline
\end{tabular}


Soruya yapılan yorumlar incelendiğinde özel zaman ayıramayan katılımcı müzik öğretmenlerinin ders saati yoğunluklarını ve taşımalı eğitimin okul dışı zamanlarda çalışmayı engellemesini sebep olarak belirttiklerine ulaşılmıştır. Okullarda yoğun ders programları ile çalışan katılımcı müzik öğretmenlerinin ek çalışma saatleri uygulayabilmesi için gerekli müziksel donanım, kendilerine ait müzik dersliği vb eksikliklerle birlikte kaynaştırma öğrencilerine nasıl eğitim yapabilecekleri konusundaki eksiklikleri de ek çalışma zamanlarının oluşturulmasına engel teşkil ettiği düşünülmektedir. Katılımcılardan özel çalışma saati uygulayan öğretmenlerin ise kaynaştırma öğrencilerini kısmi olarak okuldaki nöbet görevinin olduğu günlerde uygun boşluklarda çalıştırması, katılımcı öğretmenin özel ilgisi ile ders dışı etkinliklere alınması ve seçmeli dersi müzik olarak seçmesine rehberlik etmesi sayesinde gerçekleşmekte olduğu bilgilerine ulaşılmıştır.

Soru 10: "Kaynaştırma öğrencilerinize çalg1 eğitimi verirken varsa sizin özel olarak geliştirdiğiniz bir yöntem, teknik veya uygulama hakkında görüşleriniz nelerdir" sorusuna katılımcıların sadece yarısı kısa cevaplar vermişlerdir. Bu kısa cevaplar içerik analizi boyutuna alınması için yeterli olmadıklarından cevap veren öğretmenlerin görüşleri genel olarak özetlenmiştir. Soruya yapılmış yorumlar incelendiğinde katılımcılar tarafından özel geliştirilmiş bir tekniğin olmadığı fakat kaynaştırma öğrencilerinin daha kolay başarması, uygulayabilmesi ve takip edilebilmesi için sınıftan yardımcı-rehber arkadaş görevlendirmeleri yaptıkları, çalgı müziği eserlerini öğretirken parçadan bütüne doğru öğretim yaptırdıkları ve tekrarlı nota okumaları ile çalışmalarını sürdürdüklerini belirtmiş oldukları tespit edilmiştir. Katılımcı müzik öğretmenlerinin özel eğitimde bir alan olan kaynaştırma eğitimi hakkında yeterli bilgi ve deneyime sahip olmamaları nedeniyle müzik öğretimini özel eğitim bilgileri ile birleştirip yeni yöntem-teknik veya uygulamalar geliştirememelerinin beklenen bir sonuç olduğu düşünülebilir. Fakat öğretmenlik eldeki şartları en iyi şekilde kullanıp en üst seviyede başarıyı yakalamayı amaç edinerek etkinliğini sürdürmeye çalışan bir meslek alanıdır. Bu açıdan öğretmenlerin her tip öğrenci eğitimiyle ilgili kendi gelişimlerinde az da olsa bireysel girişim, gelişim ve araştırmanın da önemi göz ardı edilemez. Girgin ve Baysal (2005)'e göre gelecekte önemli yerlerde olabilecek öğrencilerin yetiştirilmesi, gelişimleri, eğitimleri açısından öğretmenlik diğer mesleklerle karşılaştırıldığında stratejik açıdan önemlidir. Öğretmenlik, alan ve meslek bilgisinin yanı sıra özveri, hoşgörü, sürekli kendini yenileme, mesleği severek yerine getirme gibi özellikleri de gerektiren bir meslektir.

Soru 11: "Kaynaştırma öğrencilerimin kolaylıkla kullanabildiği çalgılar şunlardır" ifadesine verilen cevaplar incelendiğinde katılımcılar en çok kullanılandan az kullanılana doğru çalgıların: Orff çalgıları, vurmalı çalgılar, ritim çalgıları, melodika, blok flüt olduğunu belirtmişlerdir. Kaynaştırma öğrencileri tarafından ritim çalgılarının ve vurmalı çalgıların ezgisel ses çıkaran çalgılara nazaran daha çok tercih edilmesinin nedeninin daha az teorik bilgi kullanma-simge-sembol-inceleme-çözümleme-karşılaştırma gibi süreçlerle ilişkili olmasından dolayı olduğu düşünülmektedir.

Soru 12: "Kaynaştırma öğrencilerinizi de göz önüne alarak bütün sınıf için çaldırmayı düşündüğünüz çalgı eserini seçerken nelere dikkat etmektesiniz" sorusuna ilişkin analizler Tablo 8'de sunulmuştur.

Tablo 8.

Kaynaştırma Öğrencileri de Göz Önüne Alarak Bütün Sınıf İçin Çalışılması Düşünülen Çalg1 Eserini Seçerken Dikkat Edilenler

\begin{tabular}{llc}
\hline Tema & Kod & Katılımcılar \\
\hline Seviye & Sınıf seviyesine uygun seçiyorum & B,G,Ö,F \\
& Öğrencinin yapabileceği seviyede eser veriyorum & B,G \\
& Sinıfın genel durumuna göre seçim yapıyorum & Ö \\
& Kaynaştırma öğrencisine eserin tümünü değil bir kısmını & Ö \\
& çaldırıyorum & S
\end{tabular}


Eser ögeleri Yumuşak tınılı eserler veriyorum

Katılımcılar tarafindan verilen cevaplar incelendiğinde sınıf seviyesi, öğrencinin seviyesi, o ders içinde öğretilmesi düşünülen-planlanan müzik teorik-yazınsal bilgilerle ilişkili olması, yumuşak tınılı ahenge sahip olması, onaltılık nota gibi çalımı ve uygulaması güç olan nota şekillerini barındırmaması, ses değiştirici işaretlerin olmaması, ritmik yapısının sade olması ve eğlendirici olmasına dikkat ettikleri saptanmıştır. Yukarda sayılan dikkat ettikleri noktalar katılımcı müzik öğretmenlerinin normal gelişim gösteren öğrenciler içinde uyguladıkları noktalar olarak kabul edilebilir. Fakat bu önemli noktaları bilmelerine rağmen diğer sorulardan ulaşılan kaynaştırma eğitimi ile ilgili yeterli bilgi ve deneyimlere sahip olmamalarını belirtmeleri çelişkili bir durum sayılabilir. Bunun nedeni olarak da katılımcı müzik öğretmenlerinin kaynaştırma eğitimi gibi önemli bir alanda temel bilgilerinin-deneyimlerininuygulamalarının eksikliğinden doğabildiği düşünülen kaynaştırma öğrencileri ile eğitim yapabilme güvensizliği-kuşkusu olabileceği düşünülmektedir.

Soru 13: "Kaynaştırma öğrencileri çalg1 eğitiminde başarılı olamıyorlarsa sizce buna neden olan etmenler nelerdir?" sorusuna ilişkin analizler Tablo 9'da sunulmuştur.

Tablo 9.

Kaynaştırma Öğrencilerinin Çalgı Eğitiminde Başarılı Olamıyorlarsa Buna Neden Olan Etmenler

\begin{tabular}{llc}
\hline Tema & Kod & Katılımcılar \\
\hline Öğrenci & Dikkat eksikliği & B \\
& Bedenlerini tam kullanamamaları, kas gelişimi & S,Ç \\
& Sinıf ortamında yetersiz hissetmeleri & Ç \\
& Özel yetersizlik durumu & Ö \\
& Başarısızlık kaygısı taşımaları & Ö,M2 \\
& Öğrencinin müzik dersine ilgisinin çekilememesi ve & M, M2,F \\
& öğrencinin ilgisizliği & Ç \\
Ders ve program & Sadece ders süresi sınırlılığında ilgilenmek zorunda olma & Ç,G,M \\
& Bireysel çalı̧̧ma gerekliliği ve öğretmenin zaman & G \\
& ayıramaması & İ \\
& Ayrı bir program ile çalışma gerekliliği & A,Ö,I \\
\hline
\end{tabular}

Soruya verilen cevaplar incelendiğinde katılımcıların; dikkat eksikliği, fiziksel yetersizlik, sinıfta kendine güven sorunu, öğrencilere özel zaman ayıramama, bireysel ilgilenememe, eğitimin ayrı uygulanmasına ihtiyaç duyma, program, aile, çevre, engel durumları, kayg1, eğitim sistemi, derse az ilgi gibi etmenleri tespit ettikleri görülmüştür. Verilen cevaplardan da anlaşılacağı üzere kaynaştırma öğrencilerinin ve eğitimcilerinin kaynaştırma eğitiminde sıklıkla görülebilecek olan genel yetersizlikleri tespit ettikleri anlaşlabilmektedir. Teknik destek ve bilgi donanımının eğitim personeline sağlanmamasının bulgunun bu şekilde oluşmasına neden olduğu düşünülmektedir. 


\section{Sonuc}

Katılımcı müzik öğretmenlerinin kaynaştırma öğrencilerinin şarkı eğitimi ve çalg1 eğitimlerine ilişkin kendi eklemek istedikleri durumlar, sorunlar ve düşünceleri de sorulmuş ve aşağıdaki cevaplar alınmıştır. Her iki eğitim alanında da bazı öğretmenler düşüncelerini belirtmişlerdir.

"Bu sorulardan başka kaynaştırma öğrencilerinin şark1 eğitimi ile ilgili görüşleriniz, varsa belirlediğiniz problemler ve önerileriniz nedir?" sorusuna katılımcılar tarafından yapılan yorumlar incelendiğinde öğretmenlerin; kaynaştırma öğrencilerinin: sınıflardaki eğitim alma durumlarının hem karma hem de özel sınıflarda olacak şekilde değiştirilmesi gerektiği, şarkı eğitiminde daha çok güncel-popüler tarzda eserlere ağıllık verilmesi gerektiği, farklı kültür ve müzikleri tanımaları gerektiği, canlı müzik ortamlarında bulunarak müziksel deneyimlerinin artırılması gerektiği, karma sınıfta uygulanan planla değil bireysel ve ayrı ayrı planlarla eğitilmeleri gerektiği, karma sınıfların mevcutlarının düzenlenmesi gerektiği ve bol tekrarla başarı durumlarının artırılabileceği gibi düşünceler sunmuş oldukları saptanmıştır. Bu önerilerden katılımcı müzik öğretmenlerinin sınıflarındaki farklı özelliklerde olan kaynaştırma öğrencileri sayesinde birbirlerinden farklı düşünce ve öneriler sunmuş oldukları ve bu durumun her öğretmenin edindiği deneyim ve bilginin normal karşılanabilecek yapıda farklı olabileceği anlaş1labilmektedir.

"Bu sorulardan başka kaynaştırma öğrencilerinin sizce çalgı eğitimi ile ilgili görüşleriniz, varsa belirlediğiniz problemler ve önerileriniz nedir?" sorusuna yapılmış olan yorumlar incelendiğinde katılımcıların çalgı eğitimiyle ilgili olarak; ailelerin çalgılara yetersiz ilgilerinden dolayı çocukların da ilgilerinin yetersiz kaldığını ve bu olumsuz etki yıkılırsa çocukların daha başarılı olabileceğini, motivasyon eksikliğini, müzik ders sayılarının azlığını ve ders süresinin kısalığını önemle belirttikleri görülmüştür. Katılımcı müzik öğretmenlerinin belirttiği cevaplar incelendiğinde kendilerinin dışında oluşan aile ve teknik yetersizlikler konularında sıkıntı yaşanması durumlarının üzerinde durdukları önemli bir problem olduğu düşünülmektedir.

$\mathrm{Bu}$ sonuçlar 1şığında ilişkili olarak Dilsiz (2017) tarafından görme engelli ilköğretim okullarında görev yapmakta olan müzik öğretmenlerinin görme engelli öğrencileri ile yaptıkları müzik derslerine ilişkin görüş belirleme çalışması incelenebilir. Öğretmenler öğrencilerine verdikleri müzik eğitimi süresinin kısıtlı ve yetersiz olduğunu, bu nedenle etkinlikler yapabilme için firsatlarının olmadığını belirtmişlerdir. Çalgı eğitimi konusunda ise Braille alfabesi ile yazılmış kaynaklarının olmadığını, bu imkânsızlık nedeniyle öğrencilerin çalgı eğitimlerini kendi yöntem ve teknikleri yardımıyla vermeye çalıştıklarını belirtmişlerdir.

Kaynaştırma öğrencilerinin şarkı eğitimi ve çalgı eğitimleri üzerine alanda çalışmakta olan müzik öğretmeni katılımcıların durumunu tespit etmeye çalışan bu çalışmada katılımcıların hepsi kaynaştırma öğrencilerinin şarkı eğitimi performanslarına yeterli katılımı sağlayabildiklerini belirtmişlerdir. Fakat çalg1 eğitiminde katılımcıların büyük çoğunluğu şarkı eğitiminin aksi yönünde kaynaştırma öğrencilerinin çalgı eğitimi performanslarına yeteri kadar katılımı sağlayamadıklarını belirtmişlerdir. $\mathrm{Bu}$ farklılığın şarkı ve çalg1 performanslarının öğrenme, öğretme, çalışma, anlayıp pratiğe dökme, ezberleme, durumlarındaki güçlük derecesi farklılıklarından kaynaklandığı söylenebilir. Şarkı söylerken çocuk sadece sözleri ve yapabildiği kadar sesleri düşünmekte ve bu faaliyetleri yaparken etkinlik memnuniyet verici nitelikteyse mutlu olmaya da firsat bulabilmektedir. Çalgı çalma performansı ise toplu veya bireysel performans oluşturma durumuna göre ritim, hız, çalgıyı yeterli ve doğru tutma, doğru ritim kalıplarına dikkat, müziksel akışı veya ezgiyi bozmadan seslendirebilme gibi daha karmaşık süreçlerden oluşmaktadır denilebilir. Bu farklılıklar nedeniyle kaynaştırma öğrencilerinin şarkı performanslarında daha başarılı olabilmesi normal bir durum olarak karşılanabilir. Bulgu ve sonuçlara ilişkin ayrıntılı incelemeler ve kaynaştırma öğrencilerinin şarkı ve çalg1 eğitimi performanslarını geliştirebileceği düşünülen açılamalar öneriler bölümünde sunulmuştur.

\section{Öneriler}

Özel eğitimde ÖGÖ'lere koşulsuz sevgi ve saygı gösterilmelidir. Her birey engelli olabileceğini düşünebilmeli ve onlara özenle yaklaşmalıdır. ÖGÖ’lerin erken tanısından sonra erken 
eğitimlerine başlanmalıdır (Kulaksızoğlu, 2015). Ülkemizde Yirminci yüzyıldan bu yana özel gereksinimli bireylerin eğitim ve öğretimine önem verilmekte ve bu bireylerin gereksinimlerine yönelik ilk ve orta dereceli özel eğitim kurumlar açılmakta, bu konuda yasal düzenlemeler de yapılmaktadır. Son yıllarda özel gereksinimli bireyler normal akranları ile aynı ortamda, tam zamanlı, ya da yarı zamanlı olarak eğitim görecekleri kaynaştırma/bütünleştirme uygulamaları ile normal sınıflara yerleştirilmekte, ayırıcı/ayrımcı tutumlardan uzaklaşılmaktadır. Bu olumlu gelişmelere rağmen özel gereksinimli bireylerin yeteneklerine yönelik eğitim almaları noktasında bazı sıkıntılar mevcuttur (Varış ve Hekim, 2017, s. 31).

Kaynaştırma öğrencileri normal gelişim gösteren öğrencilerden farklı gelişim gösteren öğrenciler oldukları için eğitimciler tarafından oldukça dikkatli incelenmeli ve eğitimleri planlanmalıdır. Sadece müzik alanında değil tüm eğitim ve gelişim alanlarında erken tanılanması ve bu tanılanma sonrası erken ve dikkatli eğitimlere başlanması sayesinde sosyal, zihinsel, fiziksel, sağlık yönlerinden olumlu gelişmeler ele etmiş olabilecek, yaşıtlarına ve sosyal hayata daha kolay adapte olabileceklerdir.

Katılımc1 müzik öğretmenlerinin kaynaştırma öğrencilerinin de bulunduğu karma sinıflarda normal gelişim gösteren öğrenciler için uygulanan müzik eğitimi programı içindeki şarkı eğitimi ve çalgı eğitimi çalışmalarının kaynaştırma eğitimi öğrencilerine uygulanmasını ve kaynaştırma öğrencilerinin karma sınıflarda müzik eğitimi almalarını doğru bulmamaktadırlar. Kaynaştırma öğrencileri için ek bir çalışma saati koyamadıkları ve normal gelişim gösteren öğrenciler için seçtikleri şarkıları, çalg1 eserlerini kaynaştırma öğrencilerine öğretmeyi uygun bulamadıkları ve öğrettikleri zamanlarda başarı açısından verim alamadıkları için bu düşüncede olduklarını belirtmektedirler. Bu bakımdan kaynaştırma öğrencilerini yaşıtlarından ayırmamak için karma sınıftaki müzik dersinden başka bir özel sınıf müzik dersi olarak "özel gereksinimliler için müzik" veya "kaynaştırma öğrencileri için müzik" dersinin haftalık ders programına konulması ve müzik öğretmenlerinin daha rahat eğitim vermesi ve başarılı sonuçlar elde etmesine firsat sunulmalıdır.

Müzik öğretmenliği lisans programı öğrencileri son sınıfta okul deneyimi ve öğretmenlik uygulaması derslerini farklı okullarda ders izleyerek ve uygulamalar yaparak almaktadırlar. Müzik öğretmeni adayı son sınıf öğrencilerinin kaynaştırma öğrencilerini mesleğe başlamadan daha önce kısmen de olsa tanıyabilmeleri için okul deneyimi ve öğretmenlik uygulaması derslerini öncelikle kaynaştırma öğrencileri olan okullarda almalarına önem verilmesinde yarar olabilecektir. Ayrıca müzik eğitimi lisans programında verilmekte olan özel eğitim ve kaynaştırma öğrencileri için müzik dersinin özel eğitim alanında uzmanlaşmış olan akademisyenler tarafından verilmesinin öğretmen adayları için yeterli yararı sağlayamayacağı düşünülmektedir. Bu durumun çözülmesi için öğretmenlik bölümlerindeki akademik personelin kendi bölümü ile ilişkili olarak özel eğitim alanında eğitimler alması ve dersleri yürütmesinin daha faydalı olabileceği düşünülmektedir.

Müzik öğretmenlerinin hem kaynaştırma öğrencileri hem de normal gelişim gösteren öğrenciler için çağdaş müzik eğitim öğretim yöntemleri hakkında araştırmalar yapıp elde ettikleri bilgi ve deneyimleri genel müzik eğitimi çalışmalarında her tip öğrenci topluluğuna uyarlayarak kullanmaları ve öğrencilerinin daha aktif, eğlenceli müzik dersi çalışmaları içinde olmaları, kazanımlar edinmeleri için (derslerde popüler ve güncel şarkı ve çalgısal düzenlemeler vb.) özen göstermelerinin önemli başarı artışları sağlayabileceği düşünülmektedir. Müzik dersini ve eğitimcisini seven öğrencilerin her zaman kolaylıkla motive olabileceği ve başarısının da bu oranda artabileceği düşünülmektedir. Müzik öğretmenlerinin iyi planlamalar yapması ve dikkati sayesinde kaynaştırma öğrencilerine onlar farkında olmadan şarkılar aracılığıyla birçok müziksel, sosyal, akademik bilgi ve becerilerin öğretilebileceği, geliştirilebileceği düşünülmektedir.

Müzik öğretmenleri kaynaştırma öğrencileri ile şarkı eğitimine başlamadan önce öğrencilerin şarkının sözlerine 1sınmaları ve alışmaları için söz okuma çalışmaları yaptırmalarının, sözler ile ilgili küçük sorular sormalarının, ardından motiflerden başlayarak cümlelerine doğru bir geçiş sırasıyla ezgili söyleme çalışması yaptırmalarının faydası olacağı ve öğretim işini kolaylaştıracağı düşünülmektedir. Yine şarkı sözlerinin ezberlenmesi için farklı 
teknik ve uygulamaların müzik öğretmenleri tarafından geliştirilmesi sayesinde ezberleme sürecinin daha kolay olabileceği, öğrencilerin hem söyleyip, hem hareket edip hem de arkadaşları ile başka etkinlikleri daha zevkli ve kolay olarak yapabilmelerinin faydası olabileceği düşünülmektedir. Şarkı eğitimi ile ilgili nerileri en kolay ve başarılı yapabilecek bireyler kaynaştırma öğrencisi olan müzik öğretmenleridir. Öğrencisini yakından tanıma imkanı ve şansı olan müzik öğretmenleri kaynaştırma öğrencileri için basit yapıda şarkılar besteleyebilir ve şarkı eğitimi gelişimlerini dikkatle takip etme şansını elde etmiş olabilir. Yıldırım ve Albuz'a (2010) göre zihinsel engelli çocuklara şarkı öğretimi için şarkı repertuarı geliştirilmeli, zenginleştirilmeli ve eğitim müziği bestecileri bu yönde desteklenmelidir.

Kaynaştırma öğrencilerinin ve ÖGÖ’lerin çalg1 eğitimi çalışmalarının birden çok zihinsel ve fiziksel işlemin/becerinin birlikte sürdürülmesi gerekliliğinden dolayı şarkı eğitimine nazaran daha güç aktiviteler olabileceği düşünülmektedir. Bundan dolayı çalgı eserlerinde ezberleme ve dolayısıyla etkili çalabilme kabiliyetlerini artırmak için kısa eserler seçilmesinin ve eserlerin motif motif-cümle cümle eğitim sürecine yayılarak çalıştırılmasının, özellikle kaynaştırma öğrencileri için doğru çalgıların seçimi, nota ezberlenmesi gereken durumlarda farklı öğretim strateji ve yaklaşımlarının kullanımı, sınıftan ayrı ve ön çalışmalar gerekliliği ve yeterli zaman ayrılabildiği, öğrencilerin bunu başardıklarını gördükleri takdirde kendilerine güven duygularının belirli derecede artabileceği düşünülmektedir.

Müzik öğretmenleri sınıflarındaki kaynaştırma öğrencilerinin özel gereksinim türlerine göre eğitim planlamakta ve olabilecek en uygun seviyede çalg1 eğitimi faaliyetlerini sürdürmektedirler. $\mathrm{Bu}$ açıdan bakıldığında kaynaştırma öğrencilerinin çalgı çalabilecekleri düşüncesine ulaşılabilir. Fakat bazılarının özel durumlarından dolayı bilerek ya da bilmeyerek özel durumunu kullanma/faydalanma düşüncesi içinde olması ihtimali ile çalg1 çalmayı istemeyebilecekleri akla gelebilecek şüphelerden olabilir. Elbette öğrencilerini tanıyan öğretmenler bunlara göre tutum ve davranışlar açısından önlemler almalıdırlar. Tüm sınıfla birlikte aynı anda çalgı çalışma kaynaştırma öğrencileri için çok zor olabilir. Çalg1 eğitimi için kaynaştırma öğrencilerine özel zaman ayırmak gerekebilir.

Çalg1 eğitimine ilişkin ilkokul ve ortaokul derecelerinde normal gelişim gösteren öğrencilerde dahi hız ve nüans terimlerinin uygulanması çoğu zaman başarılması zor bir beceri olabilmektedir. $\mathrm{Bu}$ açıdan bakıldığında kaynaştırma öğrencileri için üst seviye bir yetenek ve anlayış gerektirebilen konu olan hız ve nüans terimlerinin uygulanabilmesinin ancak kaynaştırma öğrencisinin çalgısına çok iyi hakimiyet sağlaması sonrası sağlıklı bir şekilde uygulama kolaylığına erişebileceği düşünülmektedir. $\mathrm{Bu}$ hassas konu gereği müzik öğretmenlerinin kaynaştırma öğrencilerinin özel durumlarına ilişkin bireysel çalışmalar düşünmeleri, planlamaları ve uygulamalarının faydalı sonuçlar sağlayabileceği düşünülmektedir.

Kaynaştırma öğrencilerinin çalgı eğitimi sırasında drama ve oyunlaştırılmış etkinlikler kullandığında kaynaştırma öğrencilerinin derse olan ilgisi ve çalgı çalma etkinliklerine katılımlarının kolay biçimde artabileceği düşünülmektedir. Öğretmenlerin de görüşleri bu yönde olmuştur. Fakat bu sürecin de kaynaştırma öğrencilerinin ilgisini eğitime yeteri oranda çekebilme ve öğrencilerin yetersizlik durumlarına göre değişebileceği düşünülmektedir. Öğretmenler tarafından gerekli ön çalışmaların ve başarı süreçlerinin takip edilmesinde fayda sağlanabileceği düşünülmektedir.

Kaynaştırma öğrencilerim çalgı eserlerin notalarını yeteri kadar ezberleyebilme yeterliklerinin geliştirmesi özel gereksinim durumları ile ilişkili olarak bireysel ele alınması gereken bir durumdur. Zihinsel faaliyetler bakımından normal gelişim gösteren akranlarına göre daha sınırlı yeterliklerde olması nedeniyle ezber becerilerinin sadece müzik alanında değil diğer akademik alanlarda da kendisini bir sorun olarak gösterebileceği düşünülmektedir. Ezber ve çalgı çalma performansı iki farklı alanı (zihinsel süreçler ve fiziksel performans) aktifleştireceği için bu durun daha da zor seviyeye ulaşabilmektedir. Bu riskli beceri ve performans alanlarının müzik öğretmenleri tarafından dikkatle incelenerek çalışmalar planlanmasında fayda olabileceği düşünülmektedir. 
Kaynaştırma öğrencilerinin sınıfta bireysel olarak çalgı çalabilmektedirler ifadesine katılımc1 öğretmenler \% 60 katılıyorum \% 40 katılmıyorum şeklinde cevap vermişlerdir. Katılımcıların yarısına yakınının katılmadıklarını belirtmesi gözden geçirilmesi gereken bir durum sayılabilir. Eğitim ortamlarında ezgisel (perdeli, perdesiz, tuşlu vb) yapılı çalgıların ritim çalgılarına göre daha üst beceri ve anlama kapasitesini kullanma gerekliliğinden dolayı bu oranın ortaya çıkmış olabileceği düşünülmektedir. Kaynaştırma öğrencilerinin ezgisel-tınısalperdeli-perdesiz çalgıları kullanması yerine ritim çalgılarıyla performanslar gerçekleştirebilmeleri için gerekli plan ve eğitim süreçlerinin takip edilmesinin faydalı olabileceği düşünülmektedir.

\section{Kaynaklar}

Akıncı, M. Ş. (2017, Temmuz). Müzik eğitiminde çocuk şarkılarının seçimi: sözcükler ve sözcüklerle ilişkili etmenler. Uluslararası 3. İpek Yolu Müzik Konferansl, Müzik Eğitimi Yayınlarl, içinde (s. 130-135), Gazimağusa, KKTC.

Akınc1, M. Ş. ve Alpagut, U. (2017). Müzik öğretmenlerinin kaynaştırma öğrencilerinin genel müzik eğitimlerine ilişkin görüssleri. The Journal of International Social Research, 10$53,535-545$.

Aktaş, B. ve Çifci Tekinarslan, İ. (2016). Müzik öğretmenlerinin kaynaştırma öğrencilerine yönelik yaptıkları öğretim uyarlamalarının belirlenmesi. Bolu Abant İzzet Baysal Üniversitesi Ĕ̈itim Fakültesi Dergisi (İpek Yolu Özel Saylsi) 16, 2165-2179.

Batu, E. S. (1998). Özel gereksinimli ögrencilerin kaynaştırıldiğg bir kiz meslek lisesindeki ögretmenlerin kaynaştırmaya karşılaşılan sorunlara ilişsin görüş ve önerileri (Yayımlamamış doktora tezi). Anadolu Üniversitesi Sosyal Bilimler Enstitüsü, Eskișehir.

Çakıroğlu, O. (2016). Özel eğitimde temel kavramlar. V. Aksoy (Yay. haz.). Özel Eğitim içinde (ss. 1-20). Ankara: Pegem Akademi Yayıncılık.

Baykoç Dönmez, N., Avcı, N. ve Aslan, N. (1997, Eylül). İlk ve ortaöğretim kurumu öğretmenlerinin engellilere ve kaynaştırmaya ilişkin bilgi ve görüşleri 4. Ulusal Eğitim Bilimleri Kongresi, Eskişehir.

Büyüköztürk, Ş., Çakmak, E., Akgün, Ö. E., Karadeniz, Ş. ve Demirel, F. (2009). Bilimsel Araştırma Yöntemleri. Ankara: Pegem Yayıncılık (3. Baski).

Carey Margaretta, A. (1960). Music for the educable mentally retarded. Music Educators Journal, 46 (4).

Demir, O. Ö. (2011). Nitel araştırma yöntemleri, K. Böke (Yay. haz.). Sosyal Bilimlerde Araştırma Yöntemleri içinde (ss. 273-306). (3. Bask1). İstanbul: Alfa Yayıncılık.

Diken, H. İ. ve Sucuoğlu, B. (1999). Sınıfında zihin engelli çocuk bulunan ve bulunmayan sınıf öğretmenlerinin zihin engelli çocukların kaynaştırılmasına yönelik tutumlarının karşılaştırılması. Ankara Üniversitesi Eğitim Bilimleri Fakültesi Özel Eğitim Dergisi, 2(3), 25-39.

Dilsiz, Z. (2017). Görme engelli ilköğretim okullarında müzik dersi sürecine ilişkin ögrretmen görüşleri (Yayımlanmamış yüksek lisans tezi). Gazi Üniversitesi Eğitim Bilimleri Enstitüsü, Ankara.

Çakır Doğan, C. (2011). Türkiye'de ilköğretim düzeyindeki eğitilebilir zihinsel engelliler için müzik eğitiminin durumu ve ögretim programı modeli önerisi (Yayımlanmamı̧ yüksek lisans tezi). Ankara: Gazi Üniversitesi, Eğitim Bilimleri Enstitüsü.

Eren, B. (2012). Müzik Eğitiminde Kaynaştırma Uygulamaları ve Orff-schulwerk. Trakya Üniversitesi Eğitim Fakültesi Dergisi, 2(2), 14-25.

Ersoy, A. ve Yalçınoğlu, P. (2012). Nitel araştırmaya giriş. (çeviri kitap, Orj. Corrine Glesne). Ankara: Anı Yayınc1l1k.

Girgin, G. ve Baysal, A. (2005). Zihinsel engelli öğrencilere eğitim veren öğretmenlerin mesleki tükenmişlik düzeyi ve bazı değişkenler (İzmir örneği). Pamukkale Üniversitesi Ë̆itim Fakültesi Dergisi, 18(19), 1-10. 
Güven, E. ve Tufan, E. (2010). Kaynaştırma sınıflarında işbirlikli öğrenme yöntemi ile müzik dersleri. Uludă̆ Üniversitesi Ĕ̈itim Fakültesi Dergisi 23(2), 557-573.

Güven, E. ve Tufan, E. (2010, Nisan). Kaynaştırma uygulamasının yapıldığı ilköğretim okullarında müzik eğitimi (Balıkesir Örneği). ÇOMÜ Eğitim Fakültesi Güzel Sanatlar Eğitimi Bölümü, II. Güzel Sanatlar Eğitimi Sempozyumu, Çanakkale.

Güven, E. (2011). Müzik dersleri ve kaynaştırma uygulaması. Kastamonu Eğitim Dergisi, 19(3), 709-718.

Güven, E. (2011). Kaynaştırma uygulamasının yapıldığı sınıflarda işbirlikli ögrrenmenin müzik ögretimi üzerindeki etkileri (Yayımlanmamış doktora tezi). Gazi Üniversitesi Eğitim Bilimleri Enstitüsü, Ankara.

Karasar, N. (2009). Bilimsel Araştırma Yöntemi. Ankara: Nobel Yayıncılık (19. Bask1).

Kargın, T. (2004). Kaynaştırma: Tanımı, gelişimi ve ilkeleri. Ankara Üniversitesi Eğitim Bilimleri Fakültesi Özel Ĕ̈itim Dergisi, 5(2), 1-13.

Kırcaali-İftar, G. (1992). Kaynaştırma becerileri öz-değerlendirme arac1. Anadolu Üniversitesi Eğitim Fakültesi Dergisi, 5, 119-129.

Kulaksızoğlu, A. (2015). Farklı gelişen çocuklar. Ankara: Nobel Yayıncılık (2. Baskı).

MEB. (2000). Özel Ĕ̈itim Hizmetleri Yönetmeliği.

MEB. (2008). Özel ögretim kurumlarl genel müdürlüğ̈̈, özel eğitim ve rehabilitasyon merkezi zihinsel engelli bireyler destek ĕgitim programı. Ankara.

MEB. (2015). Özel eğitim ve rehberlik hizmetleri genel müdürlügü: kaynaştırma yoluyla eğitim uygulamaları kitapçı̆̆ı. Erişim adresi: orgm.meb.gov.tr/meb_iys_dosyalar/ 2015_07/24014806_kaynastirma1.sra.pdf

MEB. (2016). Milli eğitim istatistikleri-örgün Ĕ̈itim. Ankara.

Palancı, M. (2013). Özel gereksinimli çocuklar. Ş. I. Terzi (Yay.haz.). Eğitim Psikolojisi içinde (ss. 477-509). Ankara: Pegem Akademi Yayınc1lik.

Sevinç, B. (2011). Survey araştırması yöntemi. K. Böke (Yay. haz.). Sosyal Bilimlerde Araştırma Yöntemleri içinde (ss. 231-272). (3. Bask1). İstanbul: Alfa Yayıncılık.

Özkan Yaşaran, Ö. (2009). Normal gelişim gösteren ögrencilerin özel gereksinimli bireylerin sosyal kabullerini sağlamada kaynaştırmaya hazırlık etkinliklerinin etkisi (Yayımlanmamış yüksek lisans tezi). Anadolu Üniversitesi Eğitim Bilimleri Enstitüsü, Eskişehir.

Sucuoğlu, B. ve Kargın, T. (2010). İlköğretimde kaynaştırma uygulamaları. Ankara: Kök Yayincilik.

Uysal, A. (1995). Öğretmen ve okul yöneticilerin zihin engelli çocukların kaynaştırılmasında karşılaşılan sonuçlara ilişkin görüşleri (Yayımlanmamış yüksek lisans tezi). Eskişehir: Anadolu Üniversitesi, Sosyal Bilimler Enstitüsü.

Uysal, A. (2004). Kaynaştırma uygulaması yapan öğretmenlerin kaynaştırmaya ilişsin görüşleri, A. Kontrot (Yay. haz.). 13. Uluslararası Özel Eğitim Kongresi Bildirileri- Özel Eğitimden Yansımalar, içinde (ss.121-135). Ankara: Kök Yayıncılık,.

Varış, A. V. ve Hekim, M. M. (2017). Özel gereksinimli bireyler ve müzik eğitimi. Gazi Eğitim Bilimleri Dergisi, 3(3), 29-42

Yıldırım, P. ve Albuz, A. (2010). Zihinsel engelli çocuklara kavram öğretiminde müziğin kullanımına ilişkin öğretmen görüşleri. Erişim adresi: load/gecicimakale_dosyalari /NWSA-3225-1-1. (06 Ağustos 2013).

\section{Extended Abstract}

\section{Introduction}

Inabilities may negatively affect the social, emotional, mental, academic, cultural, and other developmental features of an individual. When considered educationally, inabilities other than certain physical ones, may also have a direct negative impact on educational activities, and can hinder the process. Individuals who fail to show progress in the expected/average developmental features when compared to their peers are defined as students with special needs 
(SWSN). SWSNs pursue their education at schools offering special education in line with the type of their needs (visually impaired, students with mental disabilities etc.) or at general educational environments with their friends who reveal normal developmental features. Such implementations are executed and followed through the laws on special education services, and are referred to as educational practices through inclusive education. Students who receive an education in the same educational environment with their friends revealing normal developmental features, take different number of lessons in different forms. Music lesson is one of these lessons which they take in theory and practice. Music lesson has a form in which students can experience the interaction more intensely, providing them with the opportunity to express themselves individually and as a group. When the content of the lesson is analyzed, it can be figured that it consists of three main stages of music education: music theory education, song and instrument teaching. However, in inclusive educational activities, it is thought that SWSNs are unable to benefit from the positive effects of music lesson enough, in terms of both other course domains and our subject. Special education course started to be offered at the departments of teaching in education faculties as of 2006-2007 academic year; and those who graduated before were unable to benefit from this course. Besides, no seminar or workshop activities have been provided for these graduates by the Ministry of National Education in this regard. Special education courses offered at the faculties are also taught by field specialists; however, there is no sound information transfer between special education and music teaching, which is necessary. Inclusive students proceed their musical education at general education/mixed classes, along with their friends showing normal developmental features. However, these lessons are designed for students demonstrating normal developmental progress. In addition to that, there are no music lessons designed for inclusive students due to reasons; such as insufficient amount of teachers, classroom shortage, or lack of inclusive students, and not having a special classroom as a result. It is possible to see inexperienced intern music teachers assigned in schools for visually or hearing impaired or for students with mental disabilities. With this in mind, aim of this study is to analyze the song and instrument teaching provided for inclusive students by music teachers working at schools; identify possible problems; and to provide suggestions. The study is considered important in terms of; providing the opportunity to assess the situation and offer solutions for the identified problems with the help of the opinions conveyed by the field teachers; contributing to the literature and serving as a guideline for the limited amount of researches in the field of SWSNs and art/music teaching; encouraging further studies; providing knowledge for music teachers, and contributing to their professional development.

\section{Method}

Following the literature review, it is found that the number of studies conducted in this field are rather low and that they mostly focus on special education instead of music teaching. Population of this research consists of all music teachers who provided inclusive education in Bolu province. Sample of the research, on the other hand, consists of a total of 10 music teachers who gave or still give inclusive education, and work in 9 elementary schools in the central district of Bolu province. The study is in the form of situation assessment and scanning model; and the data have been collected by means of a semi-structured interview form applied by researchers to the teachers at schools where they work. Following the literature review, questions were prepared on three main stages of music education: music theory education, song and instrument teaching. The questions were reviewed by two specialists in the field of music and special education, and the interview form was prepared. Findings have been obtained through qualitative content analysis method. After the analyses were completed, they were reviewed by two specialists in the field of music and special education, and suggestions were provided on the identified results as per the specialist approval. 


\section{Results}

Music teachers have stated that; participation of inclusive students in song teaching is high; they are able to fulfill different musical interpretation skills during song performances to a certain extent; their ability to memorize the song lyrics is adequate; their interest and skills are improved with the help of dramatization; they are able to offer individual song performances; they can follow the song lyrics along with the class adequately; they are rather successful and interested in current and pop songs; their general achievement level in song learning is high; they do not spare time for song learning due to several reasons; teachers cannot take the features of inclusive students into account while selecting songs due to having regular students in the class as well; they pay attention to the message and expression of the songs while selecting them; they do not have a new, individual teaching-practice technique to apply to inclusive students; and their song performances are better than their abilities in instruments.

When it comes to instrument performances, teachers have stated that; inclusive students do not participate in instrument teaching performances that much; they fail to reveal certain musical interpreting skills effectively during instrument performances; their interest and skills are developed with the help of dramatization techniques; teachers do not have a new, individual teaching-practice technique to apply to inclusive students; they assign a sufficient amount of school counsellors able to assist and follow inclusive students during instrument performances; they rather prefer rhythm and percussion instruments; and they tend to pick simple songs while selecting instrument pieces in order to increase the participation and achievement of inclusive students. It is observed that half of the participant teachers are of the opinion that; inclusive students are able to memorize the notes of instrument pieces at a certain level, they can follow the notes while performing instrument pieces to a certain extent; some of them are successful in terms of delivering individual instrument performances; some of them are successful in terms of the general instrument teaching performances; teachers are unable to apply an additional instrument education other than those which inclusive students take with their friends; and inclusive students are not successful enough due to reasons such as self-confidence issues, inability to have the full control of the instrument, and attention deficit problems.

\section{Recommendation}

In order not to separate inclusive students from their peers, "music for students with special needs" or "music for inclusive students" lesson must be added to the weekly course schedule of mixed classes as an additional music lesson besides the regular one. Music teacher candidates who study their senior years at universities must fulfill their teaching internships at schools where inclusive students are present, in order to get to know these students better, beforehand. It is believed to be important that the special education course in the curriculum of music education at bachelor level is taught by an academic who is an expert in the field. It is also believed that the utilization of contemporary music teaching methods both for inclusive and regular students, and selection of current and popular songs and instrumental compositions in order to make students more active in the class will increase the achievement level of students considerably.

It is thought to be useful if the teachers conduct lyric reading practices in order for the students to get used to the lyrics before starting to learn a song; and have the students ask small questions about the song and then apply a teaching method proceeding from part to whole in terms of melody and lyrics. Besides, it is suggested that combination of lyrics with dance and body movements will substantially facilitate the teaching process.

In order to improve the memorization and effective playing skills of inclusive students in instrument practices, it is believed to be important to select short pieces, practice them from part to whole, select the right instruments for inclusive students, and to apply different teaching methods, strategies and approaches in cases where memorizing musical notes is required. 